UDK 336.1/.5(4-67):336.27

Primož Dolenc

Preliminary paper

Prethodno priopćenje

\title{
FISCAL SUSTAINABILITY OF EU MEMBER STATES IN THE CONTEXT OF CURRENT FINANCIAL CRISIS
}

\begin{abstract}
This paper tackles the question of fiscal sustainability in current times of financial/economic crisis. Our literature review leads us to conclusion that when fiscal sustainability is being considered, putting fixed limit to public debt-to-GDP and budget balance-to-GDP ratio is a too simplified solution and that sustainable fiscal policy might be defined with public debt-to-GDP and budget balance-to-GDP ceilings, but taking into account some underlying country specific parameters. Our empirical analysis shows that most EU Member States entered year 2008 with healthy public finances. However, most EU Member States now face fiscal difficulties. Even more: almost all EU Member States would have to decrease budget deficit in 2009 and 2010, in order to achieve sustainable budget position. The extensive jumps in fiscal deficits in 2009 and 2010, compared to 2007 (before crisis), are mainly due to lower fiscal incomes as a consequence of lower economic growth and policy measures for tackling financial/economic crisis. We argue that these changes in fiscal deficits are not sustainable. Our analysis shows that in 2009 about 2/3 of the economies in question should have budget surplus, taking into consideration other relevant macroeconomic variables, such as economic growth, etc. In 2010, however, a more loosened fiscal policy would be possible, but still significantly lower fiscal deficit than forecasted would be sustainable.
\end{abstract}

\section{Key Words}

public finance, sustainability, budget balance, budget deficit, public debt

\section{JEL Classification Codes}

E62, H72, H74

\section{INTRODUCTION}

In the last financial/economic crisis the governments were forced to undertake necessary policy actions to overcome economic slowdown. In 2008 and 2009 most of EU policy makers (similar also in the USA and other economies) introduced some policy measures that usually involved massive amounts of public funds, used directly or indirectly, aiming to boost economic growth, tackle liquidity problems of banking sector, etc. The use of public funds resulted in many academic and professional debates (see e.g. Balassone et al. 2009, Spilimbergo et al. 2008, Daniel and Shiamptains 2008, Baldacci, Gupta and Mulas-Granados 2009, Leigh and Stehn 2009, Afonso and Rault 2008); especially regarding the fiscal sustainability of such actions. Data shows that fiscal situation significantly worsened in most EU Member States in 2009 and (forecasted) in 2010, compared to 2010.

For EU Member States (or at least for EMU Member States) there are two limits (Maastricht fiscal criteria), under which fiscal policy is considered to be sustainable: $3 \%$ of GDP for budget deficit and $60 \%$ of GDP for public debt are politically accepted as long-term sustainable. When Maastricht criteria were first introduced they implicitly implied that an economy, fulfilling these criteria, cannot suffer from fiscal difficulties; it tends to have 
healthy public finances. Later on, many academic debates and empirical studies ${ }^{1}$ show that the two Maastricht fiscal criteria were politically motivated and really do not have a strong theoretical and/or empirical background (as regards to fiscal sustainability as such).

Many authors argued that it is unreasonable or economically irrational to limit a member state of Euro-area (EMU) with its fiscal policy, because with the adoption of single European currency a country already loses its monetary policy. These debates started mostly soon after the acceptance of the criteria and stopped immediately after most of EU member states successfully adopted euro in 1999. And further, it is the fact that most of (also academic) critics of Maastricht criteria originated from countries, where public debt and budget deficit were significantly higher than a defined limit (that is mostly from Italy and Belgium). However, these debates all stand on common critics of administratively defined $3 \%$ and $60 \%$ which cannot guarantee per se a fiscal sustainability ${ }^{2}$.

However, current Stability and Growth Pact require countries not only to fulfill these two conditions, but to have their cyclically adjusted balances close to zero. EMU Member States and countries aiming to join are urged to comply with the budgetary requirements of EMU by avoiding excessive deficits, keeping debt levels below the $60 \%$ of GDP reference value, and respecting the "close to balance or in surplus" requirement of the Stability and Growth Pact (see e.g. Afonso and Rault (2008) for more details). But also this interpretation raises several practical questions, one being long-run horizon and how to measure it technically. Models have been developed for long-run sustainability assessment, but they are rather unpopular in their practical use; at least because there is no clear cut such as - for example - $3 \%$ and $60 \%$ of GDP for budget balance and public debt, respectively.

Slovenia is a good example of the above mentioned dilemmas about real term fiscal sustainability. Even though fiscal criteria were in accordance with the Maastricht criteria well before Slovenia actually entered EMU in 2007, empirical study clearly showed a doubtful sustainability of public finances in the period before 2004 (see Dolenc 2006). However, in 2005 and 2006 the situation changed and with higher economic growth (see Žižmond and Novak 2006), lower cost of public debt financing, and even budget surplus in recent years, Slovenia was not only in accordance with the Maastricht Criteria, but also and most importantly in accordance with the objective criteria for fiscal sustainability (see Dolenc 2007).

This paper tackles the mentioned dilemmas and focuses on one possible solution in determining the objective limitations for policy makers in EU economies. The aim of the article is to clarify if sustainability criteria could really be simplified to fixed public debt-to-GDP and budget balance-to-GDP ratio as in Maastricht criteria. We would like to find a pragmatic definition of fiscal sustainability, i.e. an operative definition that would be simple to understand and calculate. Further, we would like to assess realistic estimates of fiscal sustainability of EU Member States and determine if EU Member States in fact have any space to tackle financial crisis.

Our analysis of theoretical literature confirms that putting fixed limit to public debt-to-GDP and budget balance-to-GDP ratio is a too simplified solution if one aims at estimating/determining, what the sustainable fiscal position of an economy really is. Further,

1 For example Pasinetti (1998), Papadopoulos and Sidiropoulos (1999), Fatás and Mihov (2003), Eichengreen and Wyplosz (1998) and others.

2 For the pro and contra of the suitability of EU fiscal surveillance rules see Dabrowski et al. (2005). 
the review of theoretical and empirical solutions leads us to conclusion that sustainable fiscal policy might be defined with public debt-to-GDP and budget balance-to-GDP ceilings, but taking into account some underlying country specific parameters, but taking into account some underlying parameters that are country specific.

In the empirical part we find that most EU Member States entered year 2008 with healthy public finances, measured with selected sustainability criteria. However, in recent times of financial/economic crisis most EU Member States face fiscal difficulties and most of them are currently not fiscally sustainable due to increased fiscal expenditures, applying selected sustainability measures. Even more: our analysis shows that almost all EU Member States would have to decrease budget deficit in 2009 and 2010 in order to achieve sustainable budget balance.

And finally, we estimate that massive fiscal deficits which can be noticed in 2009 and are forecasted for 2010, or more precisely, the extensive jumps in fiscal deficits compared to 2007 (before crisis), mainly originate from lower fiscal incomes as a consequence of lower economic growth and policy measures for tackling financial/economic crisis. In this context, however, we can argue that these changes in fiscal deficits are not sustainable and thus too high. Our estimates predict that in 2009 about two thirds of the economies in question should have budget surplus, taking into consideration other relevant macroeconomic variables such as economic growth, etc. In 2010, however, a more loosened fiscal policy would be possible, but still significantly lower fiscal deficit than forecasted would be sustainable.

The rest of the paper is organized as follows. Section 2 reviews some theories and empirical studies on fiscal sustainability and introduces the underlying theory of our empirical analysis. In section 3 data and methodology are described. Section 4 with its three subsections concentrates on the results of the analysis and offers a discussion on these results. We sum up with concluding remarks and some policy implications.

\section{ON FISCAL SUSTAINABILITY}

Academic studies on fiscal sustainability are of two types: 1) studies that focus on cointegration between public revenues and consumption; and 2) studies that analyze the sustainability of fiscal position through the perspective of (if we simplify) sustainable (growth of) public debt on condition of some macroeconomic parameters. In the next two subsections we present the main assumptions and arguments of these studies, and in subsection 2.3 we present some relevant empirical studies about fiscal policy in economic downturns in the context of fiscal sustainability.

\subsection{Cointegration of public revenues vs. consumption as a concept of sustainability}

According to these studies a fiscal policy is sustainable if budget consumption follows budget revenues; i.e. given positive public debt, fiscal position tends to be sustainable if budget consumption follows budget revenues and public debt is being serviced normally. Such analyses are usually based on partial equilibrium model and assume no future changes in structural form of the economy and apply to data some kind of autocorrelation and cointergation tests and in fact analyze if public revenues follow adequately public consumption (and vice versa) on long-run. 
Hamilton and Flavin (1986) and Wilcox (1989) argue that fiscal policy is sustainable on longrun if public debt is integrated in the first level and if the change of public debt and primary public balance are stationary. There are two drawbacks of this test: 1) fixed interest rate on public debt is assumed; and 2) the analysis gives only alternative answers: public finances are sustainable or not.

Trehan Bharat and Walsh (1988) argue that in order to be fiscally sustainable primary public balance must be cointegrated with public debt, where the cointegration factor should be the interest rate on public debt. Despite alternative formulation this analysis suffers from the same two problems and prior analyses. In 1991 they presented a new version of empirical testing where they overcame the problematic assumption of fixed interest rate (see Trehan Bharat and Walsh 1991).

Hakkio and Rush (1991), Ahmed and Rogers (1995) and Quintos (1995) made a step forward, allowing also weak sustainability and not only two alternative answers (sustainable or nonsustainable fiscal policy). According to the authors, public finances are weakly sustainable if: a) both public revenues and public consumption expenses are integrated in the first level; b) public revenues and public consumption expenses are cointegrated with coefficient between zero and one; and c) residuals are stationary.

Bohn (1998) offers another solution, i.e. testing the cointegration of primary public balance with public debt, where cointegration coefficient should be greater than 0 for the public finances to be sustainable.

Cointegration analyses of public revenues and consumption as a concept of sustainability have some advantages and disadvantages. The advantage of such an analysis is that it is a firm indicator of the sustainability of fiscal policy in a selected economy. However, such an analysis can also suffer from major drawback: it could be difficult to understand, especially for non-academic society and those who are not familiar with econometric analysis.

The other group of analyses gives such answer, especially Pasinetti's approach adopted also in our empirical study ${ }^{3}$.

\subsection{The sustainable growth of public debt}

These studies usually seek for the optimal level or growth of public debt. Fiscal policy tends to be sustainable if budget deficit does not change (significantly) public debt-budget incomes ratio (Easterly et al., 1995).

Many authors ${ }^{4}$ have focused on the problem of sustainable (growth of) public debt, most of them trying to define the optimal level of public debt with one of the basic macroeconomic identities - the so called (dynamic) budget constraint. Blanchard et al. (1990), for example, methodologically solved the question of optimal level of public debt and implicitly set the framework for the analysis of public finances sustainability. The authors argue that the

Pasinetti (1998) argues that public debt-to-GDP ratio and budget balance-to-GDP ratio are connected with well defined relation and that $3 \%$ and $60 \%$ of Maastricht limits have no serious underlying argumentation.

4 For example Blanchard et al. (1990), McCallum (1984), Papadopolous and Sidiropoulos (1999), Herring (1995), De Haan and Sierman (1993), Heinemann (1993), Mac Donald and Speight (1990), Uctum and Wickens (1997), Collignon and Mundschenk (1999) and others. 
question of fiscal sustainability is mostly the question whether a country's long-term trend of public debt accumulation goes over the limit; the best indicator is therefore public debt-toGDP ratio. According to authors, fiscal policy is considered sustainable if it enables the public debt-to-GDP ratio to converge into its initial level. From this perspective, not only the level of public debt- and budget deficit-to-GDP ratio matter, but also interest rate on public debt and economic growth. However authors did not fully solve the question of optimal level of public debt (and thus the question of sustainable fiscal policy) or clearly offer a numerical solution that could be used in practical analysis and concrete policy maker's dilemmas.

The later problem has been solved by Pasinetti in his "... Myth (or Folly) of the Maastricht criteria" (Pasinetti 1998), offering a solution that can be easily applied to specified economy. His critic of the Maastricht treaty is in that it does not even mention the concept of public finances sustainability nor it defines the relation between public debt-to-GDP ratio (as one limit or criteria) and budget deficit-to-GDP ratio (as the other limit or criteria) . $^{5}$ Pasinetti shows that public debt-to-GDP ratio and budget balance-to-GDP ratio are connected with well defined relation which enables also the analysis of fiscal sustainability leading to two simple conditions for sustainable fiscal position ${ }^{6}$ :

$$
\begin{aligned}
& \frac{D}{Y} \geq-\theta_{n} \cdot \frac{B}{Y} \text { and } \\
& \frac{D_{p}}{Y} \geq\left(i-\theta_{n}\right) \cdot \frac{B}{Y},
\end{aligned}
$$

where:

- $\quad D=-d B$ - total (yearly) budget balance (this defines the change of public debt in one year),

- $D_{p}-$ (yearly) primary budget balance,

- $B>0$ - public debt,

- $Y$ - nominal GDP,

- $\theta_{n}$ - yearly nominal growth of GDP.

- $\quad i-$ (yearly) nominal interest rate on public debt.

In this way Passinetti's solution offers a good (and in fact simple) analytical tool for the determination of the flexibility of fiscal policy. These two rules could also be used in recent times of expansive fiscal policy used to ease the effects of financial and economic crises.

According to this theoretical model we can conclude that one cannot simplify fiscal sustainability criteria to fixed public debt/GDP and budget balance/GDP ratio (such as it is done in Maastricht fiscal criteria). Further, putting fixed limit to public debt/GDP and budget balance/GDP ratio is a too simplified solution if one is aiming to estimate, what the sustainable fiscal position of an economy really is. However, the sustainable fiscal policy might be defined with public debt-to-GDP and budget balance-to-GDP ceilings, but taking into account some underlying country specific parameters. These limits - suggested by Pasinetti (1998) - are expressed in equation [1] and [2] above.

5 We have already mentioned that current rules require from countries to have their cyclically adjusted balances close to zero.

6 Note that besides budget balance and public debt two additional factors in determining fiscal sustainability are interest rate on public debt and economic growth. 


\subsection{Relevant recent empirical literature on fiscal sustainability (with the emphasis also on financial crisis)}

Besides theoretical issues fiscal sustainability is a huge empirical challenge. There are several studies that focused on this matter, few of them for EU-15 Member States and to our knowledge none on the fiscal sustainability for EU-27 under current economic distress, therefore this paper adds a new value on this topic.

Past studies usually combine the question of fiscal sustainability with fiscal effects on fiscal policy under economic distress. Alfonso and Rault (2008) have studied fiscal sustainability in EU-15 countries for the period from 1970-2006. Authors find that most of EU-15 member states (not all!) had sound fiscal position until 2006. Authors note that the results of the analysis may question fiscal sustainability in some cases when taken individually, but the overall solvency of government public finances when considering EU-15 area as a whole is indubitably proven. These findings hold also for the immediate sub-period before the actual crisis (1992-2006).

Spilimbergo et al. (2008) surveyed the countries that have experienced severe systemic financial crisis. They show that fiscal stimulus is highly useful (almost necessary) when the financial crisis spills over to the corporate and household sectors which results in worsening of the balance sheets. Although the fiscal response is usually vast (sometimes causing questionable fiscal sustainability) the effect of the public funds "invested" highly depends on its composition (rather solely on its value). The authors argue that the room for discretionary fiscal action over prolonged periods of time is limited even in countries where the initial fiscal position appeared to be strong.

On the other hand, Leigh and Stehn (2009) analyzed fiscal responses during crises in G7 and advocate that during economic downturns fiscal policy provides too little stimulus too late, while monetary policy is a timely and powerful countercyclical instrument. Also some other authors (i.e. Gali and Perotti 2003, Lane 2003, Auerbach 2003) argue that discretionary fiscal easing, proxied by the cyclically-adjusted primary balance, generally arrived after the end of recessions, and provided a weak degree of stimulus. Authors argue that all that matters are automatic fiscal stabilizers and not discretional fiscal responses.

Balducci, Gupta and Mulas-Granados (2009) found that in times of financial crises governments usually implement fiscal and monetary stimulus packages to sustain aggregate demand and prevent a downward spiral of output. Further, Christiano, Wichenbaum and Rebelo (2009) argue that as the room for monetary easing rapidly shrinks, reflecting limited space for additional interest rate cuts and impaired monetary policy transmission channels, fiscal policy becomes the principal tool for stimulating economic recovery. It is subject of much debate whether these fiscal responses are sustainable and to what extent fiscal policy will be effective in supporting growth recovery, both in the short term and over time.(Jansen et al. 2008).

Analyzing the literature on fiscal responses to economic crisis IMF (2009a) finds, that fiscal responses lead to economic recoveries after the crisis only when financial sector's vulnerabilities are addressed without endangering fiscal sustainability. Namely, countercyclical fiscal policies - comprising discretionary budget measures and the operation of automatic stabilizers - have generally helped to shorten recession spells in advanced economies during previous crisis episodes (IMF 2009b). The evidence is more mixed, though, 
in emerging market economies where procyclical spending bias, narrow automatic stabilizers and limited credit access have constrained governments' ability to provide fiscal stimulus during adverse economic periods (Kaminsky, Reinhart and Vegh 2004). Initial fiscal conditions generally play a key role in crisis responses, in both advanced and emerging economies (Alesina et al. 2002).

To sum up some of the relevant literature in this respect we can say that fiscal policies might play an important role in boosting the economy and driving it from decline. The structure of fiscal stimulus matters here and - above all - the sustainability of such actions.

\section{DATA AND METHODOLOGY}

The analysis is based on yearly data for the period from 2000 to $2010^{7}$, where the data is obtained for all EU-27 member states. Underlying variables are those from equations [1] and [2], i.e. total and primary budget balance, gross public debt and yearly economic (i.e. GDP) growth. Definitions of total and primary budget balance and gross public debt are in accordance with ESA95 standards. These data was obtained from European Commission online database (2009).

Cost of debt was estimated as:

$$
i=\frac{\left(\frac{D_{p}}{Y}\right)-\left(\frac{D}{Y}\right)}{\left(\frac{B}{Y}\right)_{-1}} \cdot\left(1+\theta_{n}\right)
$$

where: subscript -1 denotes lagged variable for 1 period (i.e. 1 year).

There are several reasons why we estimated the cost of debt rather than simply taking into account market yield on sovereign securities (say 10-year bond):

1. not all countries have a liquid market for government securities and not all countries regularly issue such bonds,

2. a selected 10-year bond yield might not be the best estimate for the actual cost of debt servicing because of differences in public debt structure,

3. current market yields might not reflect appropriately the actual cost of debt servicing, because public debt portfolio usually incorporates current and past issues of debt, whereas market yield reflects required market yield for (say) new issues of public debt.

We found that countries are quite heterogeneous in selected variables. Thus cluster analysis was performed to find more homogenous groups of countries, where clustering variables were 2000-2007 averages of total and primary balance-to-GDP ratio, debt-to-GDP ratio, economic growth and the cost of debt. Average values of selected variables were calculated for obtained homogenous groups and analysis of variance was performed to confirm statistical differences between groups.

The following procedure was used to estimate sustainability and flexibility of fiscal policy in selected group of countries ${ }^{8}$ :

\footnotetext{
7 Data for years 2009 and 2010 are European Commission's projections.

8 Note that the presented methodology omits the effects of population ageing on sound public finances.
} 
1. Nominal interest rate on public debt for 2009 and 2010 was estimated according to equation [3], using actual estimated values for relevant variables in 2009 and 2010.

2. Sustainable total budget balance-to-GDP ratio for 2009 and 2010 was simulated under condition from equation [1], or more precisely, under condition

$$
\frac{D}{Y}+\theta_{n} \cdot \frac{B}{Y} \geq 0
$$

3. Simultaneously public debt-to-GDP for 2009 and 2010 ratio was estimated as ${ }^{9}$ :

$$
\left(\frac{B}{Y}\right)=\left(\frac{B}{Y}\right)_{-1} \cdot \frac{1}{1+\theta_{n}}-\left(\frac{D}{Y}\right)
$$

For estimates in 2009 actual data on public debt-to-GDP ratio and economic growth in 2008 was used, and in addition estimated sustainable total budget balance for 2009, whereas for 2010 simulations for 2009 were applied.

4. Also simultaneously sustainable primary budget balance-to-GDP ratio for 2009 was simulated as the sum of primary budget balance-to-GDP ratio in 2008 and simulated sustainable total budget balance-to-GDP ratio in 2009, minus total budget balance-toGDP ratio in 2008. Similarly, the sustainable primary budget balance-to-GDP ratio for 2010 was calculated, where (sustainability) simulations for 2009 were used.

5. Second sustainability condition was calculated from equation [2]. If this condition was not satisfied, parameters from steps 2 to 4 would be recalculated until both conditions [1] and [2] hold.

Historical data, estimates of selected variables and relevant forecasts are presented in Appendix 1, while relevant data for discussion is presented directly in the main text.

\section{RESULTS AND DISCUSSION}

\subsection{Summary statistics and cluster analysis}

Table 1 shows some basic statistical data for selected countries: country medians for the period 2000-2008 and group medians, standard deviations, minimums and maximums for selected variables. We can see (Table 1) that the selected group of countries is quite diversified with extensive differences mostly in fiscal policy parameters.

9 The difference between primary and total budget balance is under ESA95 standards in fact interests on public debt including flows on swaps and forward rate agreements used for debt management and represent the actual nominal cost of debt servicing. 
Table 1:

Averages on selected parameters for countries and some statistical parameters for selected variables

\begin{tabular}{|c|c|c|c|c|c|}
\hline Country & $D / Y$ & $B / Y$ & $D_{p} / Y$ & $\theta_{n}$ & $i$ \\
\hline Austria & $-1,4$ & 64,8 & 1,8 & 4,2 & 4,6 \\
\hline Belgium & $-0,1$ & 94,3 & 4,4 & 4,3 & 4,8 \\
\hline Bulgaria & 0,6 & 37,9 & 3,4 & 12,1 & 5,0 \\
\hline Czech republik & $-3,6$ & 29,6 & $-2,4$ & 6,0 & 4,3 \\
\hline Cyprus & $-2,3$ & 64,6 & 1,1 & 7,5 & 5,3 \\
\hline Denmark & 2,4 & 44,5 & 5,0 & 3,6 & 5,3 \\
\hline Estonia & 1,5 & 4,8 & 1,7 & 13,3 & 4,6 \\
\hline Finland & 4,1 & 41,4 & 5,6 & 4,4 & 4,1 \\
\hline France & $-2,9$ & 63,7 & $-0,2$ & 4,0 & 4,5 \\
\hline Germany & $-2,8$ & 65,1 & 0,2 & 2,5 & 4,4 \\
\hline Greece & $-4,8$ & 98,6 & 0,5 & 7,4 & 5,1 \\
\hline Hungary & $-6,4$ & 59,4 & $-2,0$ & 9,4 & 7,7 \\
\hline Ireland & 0,9 & 31,1 & 2,4 & 8,9 & 3,9 \\
\hline Italy & $-3,1$ & 105,8 & 2,4 & 3,9 & 4,9 \\
\hline Latvia & $-1,6$ & 13,5 & $-0,9$ & 11,4 & 6,0 \\
\hline Lithuania & $-1,5$ & 19,4 & $-0,6$ & 10,1 & 4,7 \\
\hline Luxemburg & 2,1 & 6,5 & 2,4 & 7,3 & 3,9 \\
\hline Malta & $-4,7$ & 63,7 & $-1,4$ & 5,9 & 5,5 \\
\hline Netherlands & $-0,2$ & 51,8 & 2,6 & 4,9 & 5,1 \\
\hline Poland & $-4,3$ & 45,7 & $-1,7$ & 7,8 & 6,5 \\
\hline Portugal & $-2,9$ & 58,3 & $-0,2$ & 4,2 & 4,8 \\
\hline Romania & $-2,2$ & 18,7 & $-0,1$ & 25,3 & 7,5 \\
\hline Slovenia & $-2,2$ & 27,0 & $-0,3$ & 8,8 & 6,3 \\
\hline Slovakia & $-2,8$ & 41,4 & $-1,1$ & 10,3 & 5,5 \\
\hline Spain & $-0,3$ & 46,2 & 2,2 & 7,4 & 4,4 \\
\hline Sweden & 2,3 & 51,2 & 4,2 & 4,2 & 4,0 \\
\hline United Kingdom & $-2,7$ & 41,0 & $-0,7$ & 5,3 & 5,4 \\
\hline Median & $-2,2$ & 45,7 & 0,5 & 7,3 & 4,9 \\
\hline $\begin{array}{l}\text { Standard } \\
\text { deviation }\end{array}$ & 2,5 & 25,9 & 2,2 & 4,6 & 1,0 \\
\hline Minimum & $-6,4$ & 4,8 & $-2,4$ & 2,5 & 3,9 \\
\hline Maximum & 4,1 & 105,8 & 5,6 & 25,3 & 7,7 \\
\hline
\end{tabular}

Source: European Commission online database (2009), own calculations.

Aiming to find more homogenous groups of countries, we employ hierarchical cluster analysis. The analysis confirms that selected countries are quite heterogeneous, taking into account selected variables, but there are three more homogenous groups (see dendrogram, Figure 1). Group membership is presented in Table 2 and Table 3 presents detailed statistical information about these groups, including analysis of variance for testing statistical differences between groups for all selected variables. 


\section{Figure 1:}

Dendrogram using Ward method of hierarchical clustering

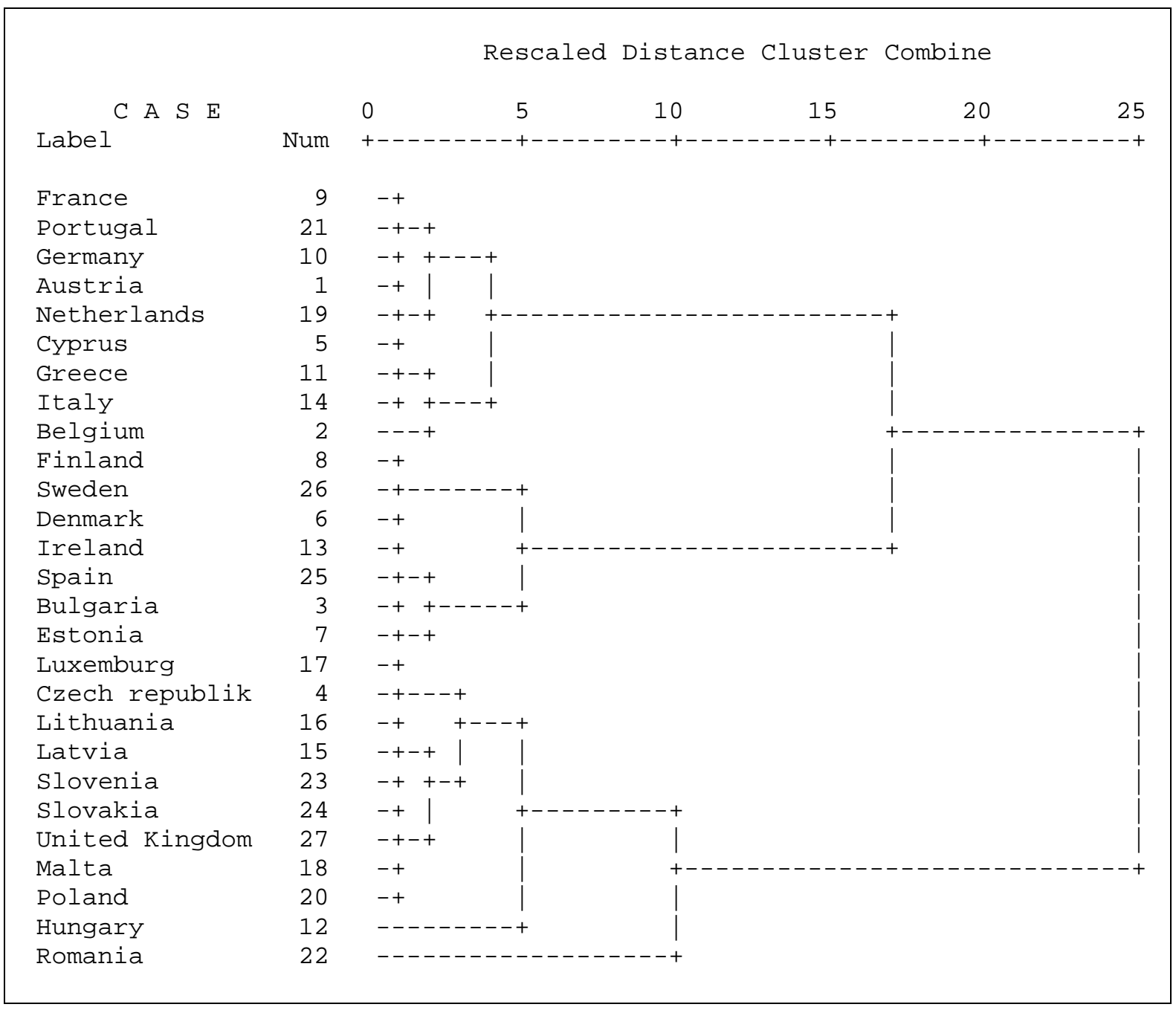

Source: Based on Figure 1.

Table 2:

Group membership according to cluster analysis

\begin{tabular}{lll}
\hline \multicolumn{1}{c}{ Group 1 } & \multicolumn{1}{c}{ Group 2 } & \multicolumn{1}{c}{ Group 3 } \\
\hline Austria & Bulgaria & Czech republic \\
\hline Belgium & Denmark & Hungary \\
\hline Cyprus & Estonia & Latvia \\
\hline France & Finland & Lithuania \\
\hline Germany & Ireland & Malta \\
\hline Greece & Luxemburg & Poland \\
\hline Italy & Spain & Romania \\
\hline Netherlands & Sweden & Slovakia \\
\hline Portugal & & Slovenia \\
\hline & & United Kingdom \\
\hline \hline
\end{tabular}

Source: Based on Figure 1. 
Table 3:

Basic statistics about selected groups and total, and ANOVA test

\begin{tabular}{|c|c|c|c|c|c|c|}
\hline Group & Parameter & $D / Y$ & $B / Y$ & $D_{p} / Y$ & $\theta_{n}$ & $i$ \\
\hline \multirow{5}{*}{$\begin{array}{l}\text { Group } \\
1\end{array}$} & Mean & $-2,8$ & 64,8 & 1,1 & 4,2 & 4,8 \\
\hline & $\mathrm{N}$ & 9 & 9 & 9 & 9 & 9 \\
\hline & $\begin{array}{l}\text { Standard } \\
\text { deviation }\end{array}$ & 1,5 & 19,8 & 1,5 & 1,6 & 0,3 \\
\hline & Minimum & $-4,8$ & 51,8 & $-0,2$ & 2,5 & 4,4 \\
\hline & Maximum & $-0,1$ & 105,8 & 4,4 & 7,5 & 5,3 \\
\hline \multirow{5}{*}{$\begin{array}{l}\text { Group } \\
2\end{array}$} & Mean & 1,8 & 39,7 & 2,9 & 7,4 & 4,3 \\
\hline & $\mathrm{N}$ & 8 & 8 & 8 & 8 & 8 \\
\hline & $\begin{array}{l}\text { Standard } \\
\text { deviation }\end{array}$ & 1,3 & 17,9 & 1,4 & 3,6 & 0,5 \\
\hline & Minimum & $-0,3$ & 4,8 & 1,7 & 3,6 & 3,9 \\
\hline & Maximum & 4,1 & 51,2 & 5,6 & 13,3 & 5,3 \\
\hline \multirow{5}{*}{$\begin{array}{l}\text { Group } \\
3\end{array}$} & Mean & $-2,8$ & 35,3 & $-1,0$ & 9,1 & 5,8 \\
\hline & $\mathrm{N}$ & 10 & 10 & 10 & 10 & 10 \\
\hline & $\begin{array}{l}\text { Standard } \\
\text { deviation }\end{array}$ & 1,6 & 17,2 & 0,7 & 5,8 & 1,1 \\
\hline & Minimum & $-6,4$ & 13,5 & $-2,4$ & 5,3 & 4,3 \\
\hline & Maximum & $-1,5$ & 63,7 & $-0,1$ & 25,3 & 7,7 \\
\hline \multirow[t]{5}{*}{ Total } & Mean & $-2,2$ & 45,7 & 0,5 & 7,3 & 4,9 \\
\hline & $\mathrm{N}$ & 27 & 27 & 27 & 27 & 27 \\
\hline & $\begin{array}{l}\text { Standard } \\
\text { deviation }\end{array}$ & 2,5 & 25,9 & 2,2 & 4,6 & 1,0 \\
\hline & Minimum & $-6,4$ & 4,8 & $-2,4$ & 2,5 & 3,9 \\
\hline & Maximum & 4,1 & 105,8 & 5,6 & 25,3 & 7,7 \\
\hline \multirow[t]{2}{*}{ Anova } & $F$ & 26,7 & 14,1 & 28,4 & 3,8 & 10,3 \\
\hline & Significance & 0,00 & 0,00 & 0,00 & 0,04 & 0,00 \\
\hline
\end{tabular}

Source: European Commission online database (2009), own calculations.

The above analyses (see Table 3) show that countries of the first group have the highest average debt-to-GDP ratio (approx. 65\%), (on average) positive primary balance (primary surplus of $1 \%$ of GDP), but due to high interest payments on public debt have a relatively high average total budget deficit (2,8\% of GDP). Except Cyprus these countries are all »old « EU Member States with developed economies. They have the lowest average economic growth and intermediate cost of public debt servicing.

The second group of countries is again the group of »old « EU member states with developed economies ${ }^{10}$ with significantly lower public debt-to-GDP ratio, lower cost of public debt servicing, primary and total budget surplus and higher economic growth.

10 The exceptions in this group are Bulgaria and Estonia as new member states with low public debt, cost of debt etc. 
And in the last group there are countries that joined EU in 2004, i.e. transition economies, and United Kingdom. These have on average the lowest public debt-to-GDP ratio, high economic growth and high relative cost of public debt servicing. They also have both primary and total budget negative balance (i.e. deficit).

Note that for all selected variables between group differences are statistically significant at negligible significance level.

\subsection{Historical data on fiscal sustainability}

Past data shows that many EU member states, also those already in EMU, exceeded Maastricht criteria (see Appendix 1). For out-of-EMU countries this is not a violation of Stability and Growth Pact, but for EMU member states, this is in fact a violation. One example may be Germany and France in years 2002-2005 with more than 3\% total budget deficit, or Greece in nearly all recent years, or Austria in 2004, etc. As we can see, the forecasts for 2009 and 2010 show that most EU Member States are in fact above these limits - there are only few exceptions.

However, as argued above, we do not focus our analysis on Maastricht criteria. Our attempt is to focus on fiscal sustainability, based on selected sustainability set of criteria. Table 4 shows computed parameters (the sum of total budget balance-to-GDP ratio and economic growth, multiplied with public debt-to-GDP ratio from equation [1]) for selected countries in the period from 2001 to 2008. Most of the economies were under the limit in the past, at least in some periods. In fact, 20 of 27 EU Member States exceeded this sustainability criterion for at least once ${ }^{11}$, and 9 of 27 have violated the criterion for at least 3 subsequent years.

11 For relevant background of some countries see Jerman, Kavčič and Kavčič (2010). 


\section{Table 4:}

First sustainability measure: sum of total budget balance-to-GDP ratio and economic growth times public debt-to-GDP ratio

\begin{tabular}{|c|c|c|c|c|c|c|c|c|}
\hline Country & 2001 & 2002 & 2003 & 2004 & 2005 & 2006 & 2007 & 2008 \\
\hline & & & & - & & & & \\
\hline Austria & 1,61 & 1,29 & 0,09 & 1,68 & 1,59 & 1,69 & 2,65 & 2,23 \\
\hline Belgium & 3,48 & 3,52 & 2,46 & 4,79 & 1,26 & 4,96 & 4,17 & 1,40 \\
\hline Bulgaria & 8,07 & 4,08 & 2,87 & 6,19 & 4,88 & 6,47 & 2,74 & 4,05 \\
\hline & - & - & - & - & - & - & & - \\
\hline Czech republic & 3,84 & 5,43 & 5,22 & 0,20 & 1,81 & 0,29 & 2,23 & 0,01 \\
\hline & & - & - & & & & & \\
\hline Cyprus & 2,35 & 2,27 & 1,61 & 1,24 & 2,02 & 3,45 & 8,15 & 5,17 \\
\hline Denmark & 3,02 & 1,61 & 1,02 & 4,09 & 7,20 & 6,89 & 5,46 & 4,63 \\
\hline Estonia & 0,54 & 0,98 & 2,37 & 2,25 & 2,17 & 3,68 & 3,28 & 2,81 \\
\hline Finland & 7,41 & 5,30 & 3,22 & 4,34 & 4,12 & 6,47 & 7,87 & 5,40 \\
\hline & & - & - & - & - & & & \\
\hline France & 0,72 & 1,10 & 2,21 & 0,94 & 0,24 & 0,69 & 0,43 & 1,36 \\
\hline Germany & $1,36^{-}$ & 2,84 & $3,39^{-}$ & $2,37^{-}$ & 2,31 & 0,86 & 2,64 & 1,81 \\
\hline Greece & 3,11 & 2,31 & 3,49 & 0,78 & 1,12 & 4,78 & 3,04 & 1,34 \\
\hline Hungary & 2,72 & 2,14 & $1,22^{-}$ & $0,8 \overline{-}$ & 3,91 & $\begin{array}{r}- \\
3,89\end{array}$ & 0,36 & 0,41 \\
\hline Ireland & 5,02 & 3,24 & 2,61 & 3,40 & 4,15 & 5,32 & 2,08 & 8,22 \\
\hline Italy & 2,12 & 1,01 & 0,26 & 0,86 & $1,4 \overline{-}$ & 0,85 & 2,64 & 0,80 \\
\hline Latvia & $0,71^{-}$ & 0,91 & 0,01 & 1,43 & 2,32 & 1,99 & 2,51 & 2,07 \\
\hline Lithuania & 2,14 & 0,32 & 0,68 & 0,46 & 2,24 & 2,28 & 2,15 & 1,08 \\
\hline Luxemburg & 6,27 & 2,51 & 0,98 & 0,69 & 0,60 & 2,22 & 4,10 & 2,70 \\
\hline Malta & 5,41 & $\begin{array}{r}- \\
1,95\end{array}$ & 8,00 & 2,82 & 1,78 & 1,41 & 1,90 & 2,14 \\
\hline Netherlands & 3,40 & $\begin{array}{r}- \\
0,13\end{array}$ & $1,80^{-}$ & - & 2,03 & 3,06 & 2,58 & 3,85 \\
\hline Poland & 3,33 & 3,44 & 4,27 & 1,27 & 1,29 & 0,18 & 2,99 & 0,04 \\
\hline Portugal & 1,23 & 0,19 & $\begin{array}{r}- \\
1,59\end{array}$ & $\begin{array}{r}- \\
1,07\end{array}$ & - & $\begin{array}{r}- \\
1,18\end{array}$ & 0,58 & 1,40 \\
\hline Romania & 8,22 & 5,20 & 4,93 & 3,53 & 1,45 & 0,19 & 0,01 & 2,39 \\
\hline Slovenia & $0,87^{-}$ & 0,87 & 0,34 & 0,08 & 0,22 & 0,84 & 3,12 & 1,11 \\
\hline Slovakia & 2,29 & 4,38 & 1,57 & 2,28 & 0,31 & 0,06 & 1,54 & 0,42 \\
\hline Spain & 3,84 & 3,23 & 3,40 & 3,12 & 4,48 & 5,21 & 4,73 & \\
\hline
\end{tabular}




\begin{tabular}{lrrrrrrrr}
\hline & & & & & & & & 2,14 \\
\hline Sweden & 3,45 & 0,96 & 1,14 & 3,05 & 4,44 & 5,30 & 6,07 & 3,68 \\
\hline \multirow{2}{*}{ United Kingdom } & 2,23 & 0,01 & 0,98 & 1,25 & 1,58 & 0,31 & 0,05 & 3,94 \\
\hline
\end{tabular}

Note: Negative (i.e. unsustainable) values are in red.

Source: Own calculations based on data from European Commission online database (2009).

Similar are results for the second sustainability criterion (equation [2]): the difference between primary budget balance-to-GDP ratio and interest rate spread over economic growth, multiplied by public debt-to-GDP ratio - see Table 5. These calculations show that high(er) public debt-to-GDP ratio might not be problematic if a country sustains a sound economic growth at given interest rates and budget balances. And vice versa: low public debt-to-GDP ratio does not guarantee fiscal sustainability if economic growth and interest rates are not properly balanced, ceteris paribus budget balances (see e.g. Germany and the United Kingdom). 


\section{Table 5:}

Second sustainability measure: the difference between primary budget balance-to-GDP ratio and interest rate spread over economic growth times public debt-toGDP ratio

\begin{tabular}{|c|c|c|c|c|c|c|c|c|}
\hline Country & 2001 & 2002 & 2003 & 2004 & 2005 & 2006 & 2007 & 2008 \\
\hline Austria & 1,49 & 1,23 & 0,11 & $\begin{array}{r}- \\
1,77\end{array}$ & 1,49 & 1,62 & 2,62 & 1,98 \\
\hline Belgium & 3,38 & 3,49 & 2,58 & 4,75 & 1,18 & 4,94 & 4,15 & 1,04 \\
\hline Bulgaria & 8,05 & 4,38 & 3,04 & 6,32 & 5,14 & 6,62 & 2,82 & 4,13 \\
\hline Czech republic & 4,30 & 5,68 & 5,33 & 0,33 & $\begin{array}{r}- \\
1,86\end{array}$ & $\begin{array}{r}- \\
0,37\end{array}$ & 2,15 & 0,11 \\
\hline Cyprus & 1,99 & $\begin{array}{r}- \\
2,59\end{array}$ & 2,09 & 0,92 & 1,86 & 3,44 & 8,17 & 5,47 \\
\hline Denmark & 3,19 & 1,57 & 1,02 & 4,05 & 7,42 & 7,07 & 5,65 & 4,24 \\
\hline Estonia & 0,53 & 0,92 & 2,35 & 2,25 & 2,16 & 3,66 & 3,29 & 2,94 \\
\hline Finland & 7,36 & 5,29 & 3,07 & 4,28 & 4,17 & 6,46 & 7,92 & 5,42 \\
\hline France & 0,62 & 1,30 & 2,50 & 1,14 & $0,41^{-}$ & 0,68 & 0,29 & 1,63 \\
\hline & & - & - & - & - & & & \\
\hline Germany & 1,38 & 2,96 & $\frac{3,58}{322}$ & 2,51 & 2,45 & $\frac{0,77}{4,58}$ & $\frac{2,63}{2,80}$ & 1,70 \\
\hline Greece & 2,56 & 2,00 & 3,22 & 0,33 & 0,84 & $\begin{array}{r}4,58 \\
-\end{array}$ & $\frac{2,80}{-}$ & 0,93 \\
\hline Hungary & 2,33 & 2,97 & 1,82 & 1,34 & 4,34 & 4,47 & 0,65 & 1,06 \\
\hline Ireland & 4,94 & 3,23 & 2,56 & 3,39 & 4,13 & 5,33 & 2,00 & 8,91 \\
\hline Italy & 1,84 & 0,97 & $0,36^{-}$ & 0,69 & $\begin{array}{r}- \\
1,66\end{array}$ & 0,64 & 2,59 & 1,00 \\
\hline Latvia & 0,94 & $\begin{array}{r}- \\
0,96\end{array}$ & 0,13 & 1,30 & 2,31 & 1,96 & 2,45 & 3,31 \\
\hline Lithuania & 2,20 & $\begin{array}{r}- \\
0,36\end{array}$ & 0,64 & 0,45 & 2,17 & 2,20 & 2,06 & - \\
\hline Luxemburg & 6,26 & 2,49 & 0,97 & 0,71 & 0,59 & 2,19 & 4,07 & 2,36 \\
\hline Malta & 5,83 & - & $8,62^{-}$ & $\begin{array}{r}- \\
3,07\end{array}$ & 1,66 & 1,52 & 1,77 & 2,38 \\
\hline Netherlands & 3,37 & 0,23 & 1,94 & 0,22 & 1,95 & 3,15 & 2,56 & 3,11 \\
\hline Poland & $\begin{array}{r}- \\
3,55\end{array}$ & $\begin{array}{r}- \\
3,91\end{array}$ & $\begin{array}{r}- \\
4,77 \\
\end{array}$ & $\begin{array}{r}- \\
1,45\end{array}$ & $\begin{array}{r}- \\
1,56\end{array}$ & 0,43 & 2,89 & 0,33 \\
\hline Portugal & $\begin{array}{r}- \\
1,56 \\
\end{array}$ & 0,47 & 1,72 & $\begin{array}{r}- \\
1,25 \\
\end{array}$ & 4,21 & 1,34 & 0,49 & $\begin{array}{r}- \\
1,59 \\
\end{array}$ \\
\hline Romania & 6,45 & 4,57 & 4,73 & 3,41 & 1,47 & 0,25 & $\begin{array}{r}- \\
0,14\end{array}$ & 2,61 \\
\hline Slovenia & 1,21 & 0,55 & 0,46 & 0,19 & 0,14 & 0,74 & 3,15 & 1,04 \\
\hline Slovakia & - & $\begin{array}{r}- \\
4,26\end{array}$ & 1,37 & 2,09 & 0,48 & 0,07 & 1,43 & 0,39 \\
\hline
\end{tabular}




\begin{tabular}{lrrrrrrrr} 
Spain & 3,80 & 3,19 & 3,41 & 3,08 & 4,47 & 5,22 & 4,77 & 2,35 \\
\hline Sweden & 3,31 & 0,94 & 1,07 & 3,02 & 4,38 & 5,38 & 6,19 & 3,73 \\
\hline & & - & - & - & - & - & - & - \\
United Kingdom & 2,33 & 0,11 & 1,16 & 1,45 & 1,76 & 0,48 & 0,22 & 4,45 \\
\hline \hline
\end{tabular}

Note: Negative (i.e. unsustainable) values are in red.

Source: Own calculations based on data from European Commission online database (2009).

20 (out of 27) economies had a negative value for our second sustainability criteria - the same as above, and 10 of them have had negative values for at least three subsequent years. The most vulnerable economies in this respect are (again) Czech Republic, France, Germany, Hungary, Poland, Portugal and the United Kingdom. In 200813 (out of 27) EU Member States - similar as above - exceeded the criterion with the highest deviation again in Ireland and the United Kingdom. This means that approximately half of the selected countries exhibited sustainability problems already in $2008^{12}$ - the first year that countries really witnessed the crisis.

To sum up, we might say that selected economies entered year 2008 (and onwards) fiscally sound. Even though countries are quite diversified in fiscal balances, public debt and other parameters, the selected sustainability set of criteria shows that all countries (except two or three countries with negligible negative values) were fiscally sustainable, taking into account both sustainability measures. But in 2008 the problems with the global crisis occurred and half of the selected economies crossed the cut-off point below which the fiscal position tends not to be sustainable (according to selected two sets of criteria).

One of our aims was to identify what might the realistic estimates for fiscal sustainability of EU Member States be. We saw above that there is no simple answer to this question and that there are many "cross-section" and "time series" particularities. Estimates of parameters for fiscal sustainability vary between countries and time. However, we saw above that most EU Member States entered year 2008 with healthy public finances, measured by selected sustainability criteria. But how much free space did they have for tackling financial and economic crisis in 2009 and 2010? How much of GDP can they afford to spend for policy measures under the condition, that they remain fiscally sustainable? We try to find some answers in the next subsection.

\subsection{The question of sustainable fiscal policies in 2009 and 2010}

Policy makers (and academics) have been largely debating on policy measures that have to be undertaken in order to battle global financial and economic crisis. Usually fiscal stimuli are used, involving mass of fiscal budget funds for direct and indirect support of the economy, nationalization of banks, etc. In our analysis we would like to estimate if such stimuli are fiscally sustainable or even more, we would like to offer a plain technical solution, answering the question, how much space a country has for funding these policy measures and still sustains fiscal sustainability.

To do so, we first estimate "the sustainable primary and total budget balance" for 2009 and 2010 (individually for each country), and then calculate the difference in budget balance in

12 In 2007 there were only 3 such countries with almost negligible negative values according to this criterion. 
2009 and 2010, respectively, against 2008. This difference shows how many \% of GDP these countries can really spend on crisis policy measures, keeping other structures of fiscal policy constant (at the level of 2008).

Data shows (Figure 2) that in all countries the Maastricht 3\% limit for total budget deficit-to-GDP ratio is critically unsustainable in 2009 and 2010. In fact, 20 EU Member States would need to have budget surplus, aiming to achieve fiscal sustainability in 2009 figures are less strict in 2010, though.

\section{Figure 2:}

Estimated sustainable total budget balance (as \% of GDP) in 2009 and 2010

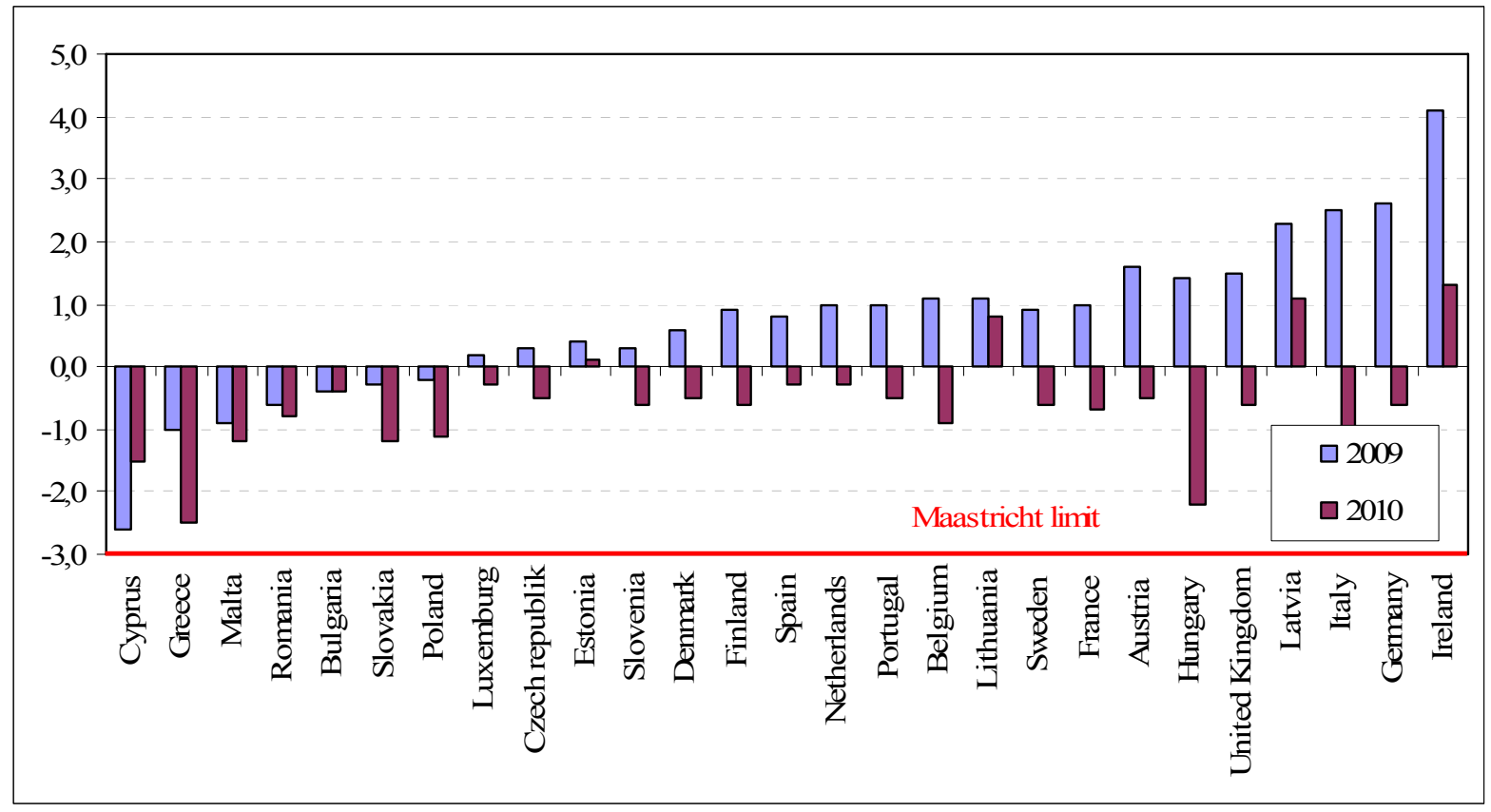

Source: Own calculations based on data from European Commission online database (2009).

However, in our opinion the differences between estimated sustainability figures and forecasted balances in 2009 and 2010, respectively, are much more relevant. These differences actually show which direction fiscal policy should follow in order to stay sustainable according to actual economic performance of selected countries. These estimates are reported in Figure 3. 
Figure 3:

\section{Estimated sustainable change in actual total budget balance (as \% of GDP) in 2009 and 2010}

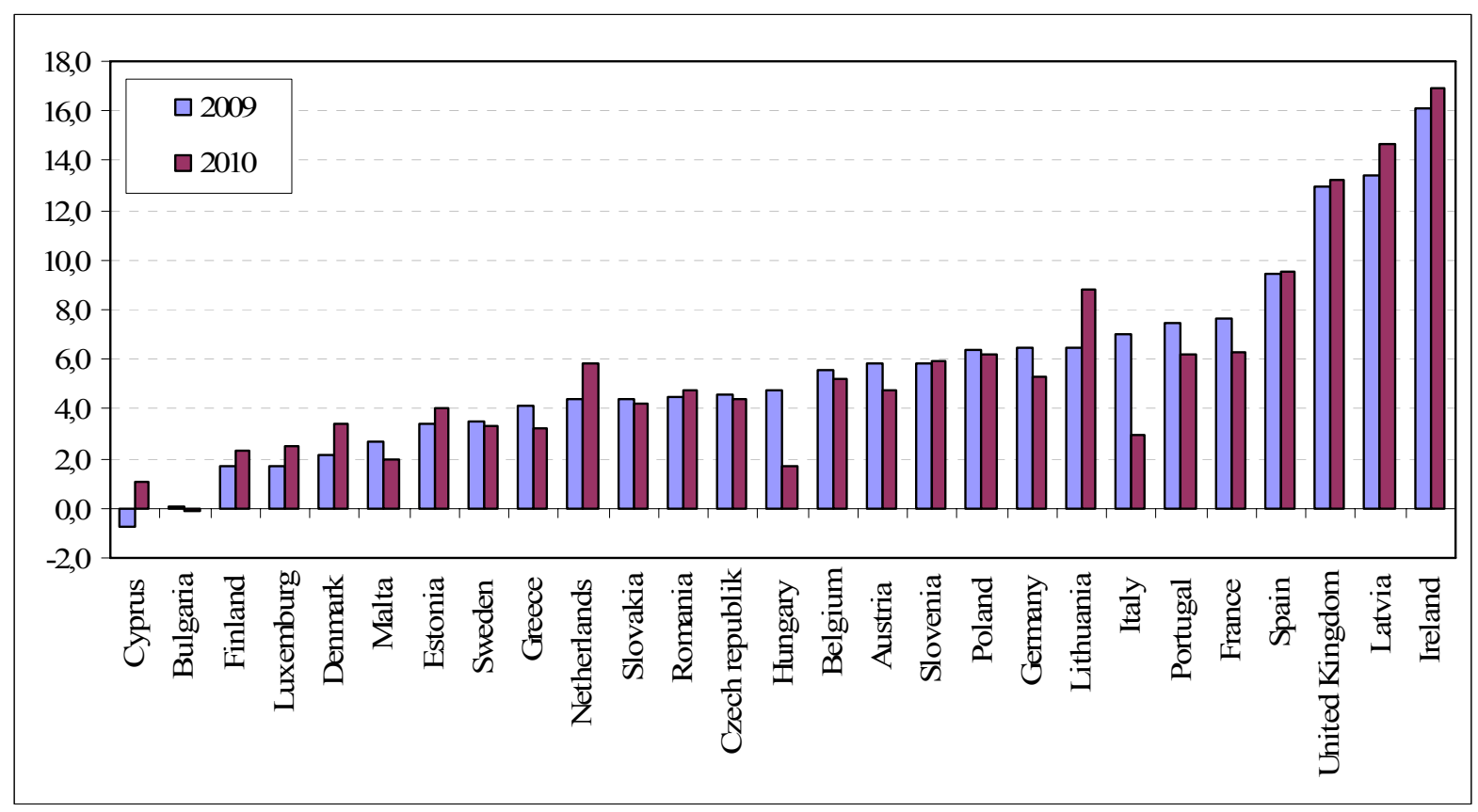

Source: Own calculations based on data from European Commission online database (2009).

Note that in order to achieve fiscal sustainability measures all of the selected countries (with two exceptions) would need a severe revision of their budgets. On average (in fact expressed by median) EU Member States would need to improve their budget balances for 5\% points compared to forecasts. High diversity of these "necessary" changes is noticed here, though. Three countries would need the most severe actions - the United Kingdom, Latvia and Ireland - with expected correction in 2010 at the level from 13 to $17 \%$ points (!).

We find that in recent times of financial/economic crisis most EU Member States face with fiscal difficulties, some member states (but not all) are not fiscally sustainable due to increased fiscal expenditures, applying selected sustainability measures. Indeed, our analysis shows that all EU Member States (with only two exceptions) would have to decrease budget deficit in 2009 and 2010 in order to achieve sustainable budget balance, taking into account relevant macroeconomic variables in the past (i.e. 2008), and in 2009 and 2010, respectively.

So, did EU Member States really have some space to tackle financial crisis? Taking into account period before actual financial/economic crisis, we saw that fiscal position was sustainable in most of EU Member States. Following this finding, we assume that massive fiscal deficits which can be noticed in 2009 and in 2010, or more precisely, the extensive jumps in fiscal deficits compared to 2008, are mainly due to lower fiscal incomes as a consequence of lower economic growth and policy measures for tackling financial/economic crisis. In this context, however, we can argue that these changes in fiscal deficits are not sustainable and thus too high. Our estimates predict that in 2009 about two thirds of the economies in question should have budget surplus, taking into consideration other relevant macroeconomic variables, such as economic growth, etc. In 2010, however, a more loosened 
fiscal policy would be possible, but still significantly lower fiscal deficit than forecasted would be sustainable.

\section{SUMMARY AND POLICY RECOMMENDATIONS}

The main idea of the presented paper was to look deeply into fiscal sustainability questions of EU member states. In recent times of financial and economic crisis all EU member states (and most other economies) tackle with necessary policy measures that have to be taken in order to preserve the economy from negative effects of the crisis. However, these steps usually cost money, and this money is usually public money. Therefore obvious question arises: will these policy measures be fiscally sustainable.

On the basis of theoretical literature we conclude that putting fixed limit to public debt-to-GDP and budget balance-to-GDP ratio is a too simplified solution if one is aiming to estimate/determine, what the sustainable fiscal position of an economy is. Further, the review of theoretical and empirical solutions leads us to conclusion that sustainable fiscal policy might be defined with public debt-to-GDP and budget balance-to-GDP ceilings, but taking into account some underlying country specific parameters.

On the basis of our calculations we argue that most EU Member States entered year 2008 with healthy public finances, measured by selected sustainability criteria. However, in recent times of financial/economic crisis most EU Member States face with fiscal difficulties and most of these states are currently not fiscally sustainable due to increased fiscal expenditures, applying selected sustainability measures. Even more: our analysis shows that almost all EU Member States would have to decrease budget deficit in 2009 and 2010, in order to achieve sustainable budget position.

We find that massive fiscal deficits which can be noticed in 2009 and in 2010, or more precisely, the extensive jumps in fiscal deficits compared to 2008, are mainly due to lower fiscal incomes as a consequence of lower economic growth and policy measures for tackling financial/economic crisis. In this context, however, we can argue that these changes in fiscal deficits are not sustainable and thus too high. Our estimates predict that in 2009 about two thirds of the economies in question should have budget surplus, taking into consideration other relevant macroeconomic variables, such as economic growth, etc. In 2010, however, a more loosened fiscal policy would be possible, but still significantly lower fiscal deficit than forecasted would be sustainable.

We conclude that EU Member States should really carefully select policy measures for tackling financial crisis, because fiscal policies in the period from 2008 to 2010 are predominantly not sustainable.

\section{REFERENCES}

Afonso, Antonio, Christophe Rault (2008). What Do We Really Know About Fiscal Sustainability in the EU? A Panel Data Diagnostic. CESifo Working Paper No. 2226. Munich: Institute for Economic Research.

Ahmed Shaghil, John H. Rogers (1995). Government Budget Deficits and Trade Deficits. Are Present Value Constraints Satisfied in Long-Term Data. Journal of Monetary Economics 36(2): 351-374. 
Alesina, Alberto, Silvia Ardagna, Roberto Perotti, Fabio Schiantarelli (2002). Fiscal Policy, Profits, and Investment. American Economic Review 92(3): 571-589.

Auerbach, Alan J. (2003). Fiscal Policy: Past and Present. NBER Working Paper No. 10023. Cambridge: National Bureau of Economic Research.

Balassone, Fabrizio, Jorge Cunha, Geert Langenus, Bernhard Manzke, Jeanne Pavot, Doris Prammer, Pietro Tommasino (2009). Fiscal Sustainability and Policy Implicatuons for the Euro Area. Frankfurt: European Central Bank.

Balducci, Emanuele, Sanjeev Gupta, Carlos Mulas-Granados (2009). How Effective is Fiscal Policy Response in Systemic Banking Crisis ? IMF Working Paper 09/160. Washington DC: International Monetary Fund.

Blanchard, Oliver, Jean-Claude Chouraqui, Robert P. Hagemann, Nicola Sartor (1990). The Sustainability of Fiscal Policy: New Answers to an Old Question. OECD Economic Studies No. 15. Paris: Organisation for Economic Co-operation and Development

Bohn, Henning (1998). The Behavior of US Debt and Deficits. Quarterly Journal of Economics 113(3): 949-963.

Christiano, Lawrence, Martin Eichenbaum, Sergio Rebelo (2009). When is the Government Spending Multipier Large? NBER Working Paper No. 15394. Cambridge: National Bureau of Economic Research.

Collignon, Stefan, Susanne Mundschenk (1999). The Sustainability of Public Debt in Europe. Economia Internazionale 1: 101-159.

Dabrowski, Marek, Antczak Malgorzata and Gorzelak, Michal (2005). Fiscal Challenges Facing the EU New Member States. CASE Network Studies and Analyses 295. Available at SSRN: http://ssrn.com/abstract $=1304862$

Daniel, Betty C., Cristos Shiamptanis. Fiscal Policy in the European Monetary Union. International Finance Discussion Papers No. 961. New York City: Federal Reserve Bank of New York.

De Haan, Jakob, Clemens L.J. Sierman (1993). The Intertemporal Government Budget Constraint: an Application for the Netherlands. Public Finance 48(2): 243-249.

Dolenc, Primož (2006). Doubtful Sustainability of Public Finances in Slovenia. Prague Economic Papers 15(3): 268-281.

Dolenc, Primož (2007). Public Debt and State Financial Assets. The Case of the Republic of Slovenia. Koper: Faculty of management Koper.

Easterly, William, Carlos Alfredo Rodriguez, Klaus Schmidt-Hebbel (1995). Public Sector Deficits and Macroeconomics Performance. Washington D.C.: The World Bank.

Eichengreen, Barry, Charles Wyplosz (1998). The Stability Pact: More Than a Minor Nuisance? Economic Policy 1(26): 65-119.

European Commission (2009). General government data.

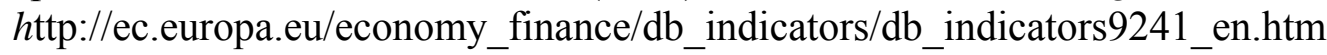

Fatás, Antonio, Illian Mihov (2003). On Constraining Fiscal Policy Discretion in EMU. Oxford Review of Economic Policy 19(1): 112-131.

Gali, Jordi, Roberto Perotti (2003). Fiscal Policy and Monetary Integration in Europe. Economic Policy 18(37): 533-572

Hakkio Craig S., Mark Rush (1991). Is the Budget Deficit 'Too Large'? Economic Inquiry 29(3): 104-118.

Hamilton James D., Marjorie A. Flavin (1986). On the Limitations of Government Borrowing: a Framework for Empirical testing. The American Economic Review 76(4): 808-819.

Heinemann, Friedrich (1993). The Sustainability of National Debt in Europe. Intereconomics 28(2): 61-68. 
Herring, Bohn (1995). The Sustainability of Budget Deficits in a Stohastic Economy. Journal of Money, Credit and Banking 27(1): 257-271.

IMF (2009a). The State of Public Finances: Outlook and Medium-Term Policies After the 2008 Crisis. Companion Paper. Washington DC: International Monetary Fund.

IMF (2009b). From Recession to Recovery: How Soon and How Strong? World Economic Outlook 2009. Washington DC: International Monetary Fund: 103-138.

Jansen, Dennis W., Qi Li, Zijun Wang, Jian Yang (2008). Fiscal Policy and Asset Markets: a Semiparametric Analysis. Journal of Econometrics 147(1): 141-150.

Jerman, Mateja, Slavka Kavčič, Bogdan Kavčič (2010). The significance of intangibles: a comparative analysis between Croatia, Slovenia, Czech Republic, Germany and the USA. Ekonomska istraživanja 23(2): 60-69.

Kaminsky, Graciela L., Carmen M. Reinhart, Carlos A. Vegh (2004). When It Rains, It Pours: Procyclical Capital Flows and Macroeconomic Policies. NBER Working Paper No. 10780. Cambridge: National Bureau of Economic Research.

Lane, Philip R. (2003). The Cyclical Behavior of Fiscal Policy: Evidence from the OECD. Journal of Public Economics 87(12): 2661-2675.

Leigh, Daniel, Sven J. Stehn (2009). Fiscal and Monetary Policy During Downturns: Evidence from the G7. IMF Working Paper 09/50. Washington DC: International Monetary Fund.

Mac Donald, Ronald, Alan E.H. Speight (1990). The Intertemporal Budget Constraint in the UK, 1961-1986. The Manchaster School 63(4): 329-347.

McCallum, Bennett T. (1984). Are Bond-financed Deficits inflationary? A Ricardian Analysis. Journal of Political Economy 92(2): 123-135

Papadopoulos, Athanasios P., Moise G. Sidiropoulos (1999). The Sustainability of Fiscal Policies in the European Union. International Advances in Economic Research 5(3): 289307.

Pasinetti, Luigi L. (1998). The Myth (of Folly) of the 3\% Deficit/GDP Maastricht 'Parameter'. Cambridge Journal of Economics 22(1): 103-116.

Quintos, Carmela E. (1995). Sustainability of the Deficit Process with Structural Shifts. Journal of Business and Economic Statistics 13(4): 409-417.

Spilimbergo, Antonio, Steve Symansky, Oliver Blanchard, Carlo Cottarelli (2008). Fiscal Policy for the Crisis. IMF Staff Position Note 8(1). Washington DC: International Monetary Fund.

Trehan Bharat, Carl E. Walsh (1988). Common Trends, the Government's Budget Constraint, and Revenue Smoothing. Journal of Economics Dynamics and Control 12(2-3): 425-444.

Trehan Bharat, Carl E. Walsh (1991). Testing Intertemporal Budget Constraints: Theory and Applications to US Federal Budget and Current Account Deficits. Journal of Money, Credit and Banking 23(2): 206-223.

Uctum, Merih, Michael Wickens (1997). Debt and Deficit Ceilings, and Sustainability of Fiscal Policies: an Intertemporal Analysis. CEPR Discussion Papers No. 1612. London: Centre for Economic Policy Research.

Wilcox David W. (1989). The Sustainability of Government Deficits: Implications of the Present-Value Borrowing Constraint. Journal of Money, Credit and Banking 21(3): 291306.

Žižmond, Egon, and Matjaž Novak (2006). Sectoral reallocation of labour as a limit on total factor productivity growth in Slovenia. Post-Communist economies 18(2): 205-228. 
Appendix I: Historical, estimated and forcasted country data for the analysis

\begin{tabular}{|c|c|c|c|c|c|c|c|c|c|c|c|c|c|c|c|}
\hline \multicolumn{2}{|l|}{$\overline{\text { Austria }}$} & \multicolumn{11}{|c|}{ Data } & \multicolumn{2}{|c|}{$\begin{array}{l}\text { Simulation } \\
\text { under the two } \\
\text { conditions }\end{array}$} & Difference \\
\hline $\begin{array}{l}\text { Variable } \\
\end{array}$ & $\overline{\text { Unit }}$ & 2000 & 2001 & 2002 & 2003 & 2004 & 2005 & 2006 & 2007 & 2008 & 2009 & 2010 & 2009 & 2010 & $2009 \quad 2010$ \\
\hline Total budget balance & $\%$ of GDP & $-1,7$ & 0,0 & $-0,7$ & $-1,4$ & $-4,4$ & $-1,6$ & $-1,6$ & $-0,5$ & $-0,4$ & $-4,2$ & $-5,3$ & 1,6 & $-0,5$ & $\begin{array}{ll}5,8 & 4,8 \\
\end{array}$ \\
\hline Public debt & $\%$ of GDP & 66,4 & 67,0 & 66,4 & 65,4 & 64,8 & 63,7 & 62,0 & 59,4 & 62,5 & 70,4 & 75,2 & 58,4 & 60,5 & $-12,0 \quad-14,7$ \\
\hline Primary budget balance & $\%$ of GDP & 1,8 & 3,4 & 2,5 & 1,5 & $-1,5$ & 1,3 & 1,1 & 2,2 & 2,1 & $-1,1$ & $-2,1$ & 4,7 & 2,6 & $5,8 \quad 4,7$ \\
\hline Growth of GDP & $\%$ & 4,8 & 2,4 & 3,0 & 2,0 & 4,2 & 5,0 & 5,3 & 5,3 & 4,2 & $-2,7$ & 0,9 & $-2,7$ & 0,9 & \\
\hline Cost of public debt & $\%$ & & 5,2 & 4,9 & 4,5 & 4,6 & 4,7 & 4,5 & 4,6 & 4,4 & 4,8 & 4,6 & 4,8 & 4,6 & \\
\hline 1st sustainability criteria & & 1,5 & 1,6 & 1,3 & $-0,1$ & $-1,7$ & 1,6 & 1,7 & 2,6 & 2,2 & $-6,1$ & $-4,6$ & 0,0 & 0,0 & \\
\hline 2nd sustainability criteria & & 5,0 & 1,5 & 1,2 & $-0,1$ & $-1,8$ & 1,5 & 1,6 & 2,6 & 2,0 & $-6,4$ & $-4,9$ & 0,3 & 0,4 & \\
\hline $\begin{array}{l}\text { Belgium } \\
\end{array}$ & & & & & & & Data & & & & & & $\begin{array}{r}\text { Simula } \\
\text { under th } \\
\text { condit } \\
\end{array}$ & $\begin{array}{l}\text { tion } \\
\text { e two } \\
\text { ons } \\
\end{array}$ & Difference \\
\hline$\overline{\text { Variable }}$ & Unit & 2000 & 2001 & 2002 & 2003 & 2004 & 2005 & 2006 & 2007 & 2008 & 2009 & 2010 & 2009 & 2010 & $2009 \quad 2010$ \\
\hline Total budget balance & $\%$ of GDP & 0,0 & 0,5 & 0,0 & $-0,1$ & $-0,3$ & $-2,7$ & 0,3 & $-0,2$ & $-1,2$ & $-4,5$ & $-6,1$ & 1,1 & $-0,9$ & $5,6 \quad 5,2$ \\
\hline Public debt & $\%$ of GDP & 107,8 & 106,5 & 103,4 & 98,6 & 94,3 & 92,2 & 87,9 & 84,0 & 89,6 & 95,7 & 100,9 & 86,0 & 88,0 & $-9,7 \quad-12,9$ \\
\hline Primary budget balance & $\%$ of GDP & 6,6 & 6,9 & 5,7 & 5,2 & 4,4 & 1,5 & 4,2 & 3,6 & 2,5 & $-0,6$ & $-2,1$ & 5,0 & 3,0 & $5,6 \quad 5,1$ \\
\hline Growth of GDP & $\%$ & 5,7 & 2,8 & 3,4 & 2,6 & 5,4 & 4,3 & 5,3 & 5,2 & 2,9 & $-1,3$ & 1,0 & $-1,3$ & 1,0 & \\
\hline Cost of public debt & $\%$ & & 6,1 & 5,5 & 5,3 & 5,0 & 4,6 & 4,5 & 4,5 & 4,5 & 4,3 & 4,2 & 4,3 & 4,2 & \\
\hline 1st sustainability criteria & & 6,1 & 3,5 & 3,5 & 2,5 & 4,8 & 1,3 & 5,0 & 4,2 & 1,4 & $-5,7$ & $-5,1$ & 0,0 & 0,0 & \\
\hline 2nd sustainability criteria & & 12,7 & 3,4 & 3,5 & 2,6 & 4,8 & 1,2 & 4,9 & 4,1 & 1,0 & $-6,0$ & $-5,4$ & 0,2 & 0,2 & \\
\hline Bulgaria & & & & & & & Data & & & & & & $\begin{array}{r}\text { Simula } \\
\text { under th } \\
\text { condit }\end{array}$ & $\begin{array}{l}\text { tion } \\
\text { e two } \\
\text { ons }\end{array}$ & Difference \\
\hline $\begin{array}{l}\text { Variable } \\
\end{array}$ & Unit & 2000 & 2001 & 2002 & 2003 & 2004 & 2005 & 2006 & 2007 & 2008 & 2009 & 2010 & 2009 & 2010 & $2009 \quad 2010$ \\
\hline Total budget balance & $\%$ of GDP & $-0,3$ & 0,6 & $-0,8$ & $-0,3$ & 1,6 & 1,9 & 3,0 & 0,1 & 1,5 & $-0,5$ & $-0,3$ & $-0,4$ & $-0,4$ & $0,1 \quad-0,1$ \\
\hline Public debt & $\%$ of GDP & 74,3 & 67,3 & 53,6 & 45,9 & 37,9 & 29,2 & 22,7 & 18,2 & 14,1 & 16,0 & 17,3 & 12,3 & 12,4 & $-3,7$ \\
\hline Primary budget balance & $\%$ of GDP & 3,7 & 4,0 & 1,5 & 1,7 & 3,4 & 3,6 & 4,4 & 1,1 & 2,4 & 0,3 & 0,4 & 0,4 & 0,4 & 0,1 \\
\hline Growth of GDP & $\%$ & 12,5 & 11,1 & 9,1 & 6,9 & 12,1 & 10,2 & 15,3 & 14,5 & 18,1 & 3,2 & 3,0 & 3,2 & 3,0 & \\
\hline Cost of public debt & $\%$ & & 5,1 & 3,7 & 4,0 & 4,4 & 4,9 & 5,5 & 5,0 & 5,8 & 5,9 & 4,5 & 5,9 & 4,5 & \\
\hline 1st sustainability criteria & & 9,0 & 8,1 & 4,1 & 2,9 & 6,2 & 4,9 & 6,5 & 2,7 & 4,1 & 0,0 & 0,2 & 0,0 & 0,0 & \\
\hline 2nd sustainability criteria & & 13,0 & 8,0 & 4,4 & 3,0 & 6,3 & 5,1 & 6,6 & 2,8 & 4,1 & $-0,1$ & 0,1 & 0,1 & 0,2 & \\
\hline Czech republik & & & & & & & Jata & & & & & & $\begin{array}{r}\text { Simula } \\
\text { under th } \\
\text { condit } \\
\end{array}$ & $\begin{array}{l}\text { tion } \\
\text { e two } \\
\text { ons } \\
\end{array}$ & Difference \\
\hline $\begin{array}{l}\text { Variable } \\
\end{array}$ & Unit & 2000 & 2001 & 2002 & 2003 & 2004 & 2005 & 2006 & 2007 & 2008 & 2009 & 2010 & 2009 & 2010 & $\begin{array}{l}2009 \quad 2010 \\
\end{array}$ \\
\hline Total budget balance & $\%$ of GDP & $-3,7$ & $-5,7$ & $-6,8$ & $-6,6$ & $-3,0$ & $-3,6$ & $-2,6$ & $-0,6$ & $-1,5$ & $-4,3$ & $-4,9$ & 0,3 & $-0,5$ & $\begin{array}{ll}4,6 & 4,4 \\
\end{array}$ \\
\hline Public debt & $\%$ of GDP & 18,5 & 25,1 & 28,5 & 30,1 & 30,4 & 29,8 & 29,6 & 28,9 & 29,8 & 33,7 & 37,9 & 28,1 & 28,9 & $-5,6$ \\
\hline Primary budget balance & $\%$ of GDP & $-2,9$ & $-4,7$ & $-5,5$ & $-5,5$ & $-1,8$ & $-2,4$ & $-1,5$ & 0,5 & $-0,3$ & $-3,2$ & $-3,7$ & 1,4 & 0,6 & 4,6 \\
\hline Growth of GDP & $\%$ & 5,2 & 7,4 & 4,8 & 4,6 & 9,2 & 6,0 & 7,8 & 9,8 & 5,0 & $-1,2$ & 1,7 & $-1,2$ & 1,7 & \\
\hline Cost of public debt & $\%$ & & 5,8 & 5,4 & 4,0 & 4,4 & 4,2 & 4,0 & 4,1 & 4,4 & 3,6 & 3,6 & 3,6 & 3,6 & \\
\hline 1st sustainability criteria & & $-2,7$ & $-3,8$ & $-5,4$ & $-5,2$ & $-0,2$ & $-1,8$ & $-0,3$ & 2,2 & 0,0 & $-4,7$ & $-4,3$ & 0,0 & 0,0 & \\
\hline 2nd sustainability criteria & & $-1,9$ & $-4,3$ & $-5,7$ & $-5,3$ & $-0,3$ & $-1,9$ & $-0,4$ & 2,2 & $-0,1$ & $-4,8$ & $-4,4$ & 0,0 & 0,0 & \\
\hline Cyprus & & & & & & & Data & & & & & & $\begin{array}{r}\text { Simula } \\
\text { under th } \\
\text { condit }\end{array}$ & $\begin{array}{l}\text { tion } \\
\text { e two } \\
\text { ons } \\
\end{array}$ & Difference \\
\hline $\begin{array}{l}\text { Variable } \\
\text { Varis }\end{array}$ & Unit & 2000 & 2001 & 2002 & 2003 & $\overline{2004}$ & 2005 & 2006 & 2007 & 2008 & 2009 & 2010 & 2009 & 2010 & $2009 \quad 2010$ \\
\hline Total budget balance & $\%$ of GDP & $-2,3$ & $-2,2$ & $-4,4$ & $-6,5$ & $-4,1$ & $-2,4$ & $-1,2$ & 3,4 & 0,9 & $-1,9$ & $-2,6$ & $-2,6$ & $-1,5$ & $\begin{array}{ll}-0,7 & 1,1\end{array}$ \\
\hline Public debt & $\%$ of GDP & 58,8 & 60,7 & 64,6 & 68,9 & 70,2 & 69,1 & 64,6 & 59,4 & 49,1 & 47,5 & 47,9 & 47,8 & 46,7 & $-1,2$ \\
\hline Primary budget balance & $\%$ of GDP & 1,0 & 1,1 & $-1,2$ & $-3,1$ & $-0,8$ & 1,1 & 2,1 & 6,5 & 3,8 & 0,4 & $-0,4$ & $-0,3$ & 0,8 & $-0,7$ \\
\hline Growth of GDP & $\%$ & 9,1 & 7,5 & 3,3 & 7,1 & 7,6 & 6,4 & 7,2 & 8,0 & 8,7 & 5,6 & 3,2 & 5,6 & 3,2 & \\
\hline Cost of public debt & $\%$ & & 6,0 & 5,4 & 5,6 & 5,2 & 5,3 & 5,1 & 5,2 & 5,3 & 4,9 & 4,8 & 4,9 & 4,8 & \\
\hline 1st sustainability criteria & & 3,1 & 2,4 & $-2,3$ & $-1,6$ & 1,2 & 2,0 & 3,5 & 8,2 & 5,2 & 0,8 & $-1,1$ & 0,1 & 0,0 & \\
\hline 2nd sustainability criteria & & 6,4 & 2,0 & $-2,6$ & $-2,1$ & 0,9 & 1,9 & 3,4 & 8,2 & 5,5 & 0,7 & $-1,2$ & 0,0 & 0,1 & \\
\hline Denmark & & & & & & & Data & & & & & & $\begin{array}{r}\text { Simula } \\
\text { under th } \\
\text { condit } \\
\end{array}$ & $\begin{array}{l}\text { tion } \\
\text { e two } \\
\text { ons } \\
\end{array}$ & Difference \\
\hline $\begin{array}{l}\text { Variable } \\
\end{array}$ & Unit & 2000 & 2001 & 2002 & 2003 & 2004 & 2005 & 2006 & 2007 & 2008 & 2009 & 2010 & 2009 & 2010 & $\begin{array}{l}2009 \quad 2010 \\
\end{array}$ \\
\hline Total budget balance & $\%$ of GDP & 2,4 & 1,5 & 0,3 & 0,1 & 2,0 & 5,2 & 5,2 & 4,5 & 3,6 & $-1,5$ & $-3,9$ & 0,6 & $-0,5$ & $\begin{array}{ll}2,1 & 3,4 \\
\end{array}$ \\
\hline Public debt & $\%$ of GDP & 51,7 & 47,4 & 46,8 & 45,8 & 44,5 & 37,1 & 31,3 & 26,8 & 33,3 & 32,5 & 33,7 & 31,7 & 32,8 & $-0,8$ \\
\hline Primary budget balance & $\%$ of GDP & 5,9 & 4,8 & 3,3 & 2,7 & 4,3 & 7,0 & 6,8 & 6,1 & 5,0 & 0,1 & $-2,3$ & 2,2 & 1,1 & 2,1 \\
\hline Growth of GDP & $\%$ & 6,6 & 3,2 & 2,8 & 2,0 & 4,7 & 5,4 & 5,4 & 3,6 & 3,1 & $-1,8$ & 1,7 & $-1,8$ & 1,7 & \\
\hline Cost of public debt & $\%$ & & 6,6 & 6,5 & 5,7 & 5,3 & 4,3 & 4,5 & 5,3 & 5,4 & 4,7 & 5,0 & 4,7 & 5,0 & \\
\hline 1st sustainability cr & & 5,8 & 3,0 & 1,6 & 1,0 & 4,1 & 7,2 & 6,9 & 5,5 & 4,6 & $-2,1$ & $-3,3$ & 0,0 & 0,1 & \\
\hline 2nd sustainability criteria & & 9,3 & 3,2 & 1,6 & 1,0 & 4,1 & 7,4 & 7,1 & 5,6 & 4,2 & $-2,0$ & $-3,4$ & 0,1 & 0,0 & \\
\hline
\end{tabular}




\begin{tabular}{|c|c|c|c|c|c|c|c|c|c|c|c|c|c|c|c|}
\hline \multirow{2}{*}{$\begin{array}{l}\text { Estonia } \\
\text { Variable } \\
\end{array}$} & \multirow[b]{2}{*}{ Unit } & \multicolumn{11}{|c|}{ Data } & \multicolumn{2}{|c|}{$\begin{array}{l}\text { Simulation } \\
\text { under the two } \\
\text { conditions }\end{array}$} & Difference \\
\hline & & 2000 & 2001 & 2002 & 2003 & 2004 & 2005 & 2006 & 2007 & 2008 & 2009 & 2010 & 2009 & 2010 & $2009 \quad 2010$ \\
\hline Total budget balance & $\%$ of GDP & $-0,2$ & $-0,1$ & 0,3 & 1,7 & 1,7 & 1,5 & 2,9 & 2,7 & $-3,0$ & $-3,0$ & $-3,9$ & 0,4 & 0,1 & 3,4 \\
\hline Public debt & $\%$ of GDP & 5,2 & 4,8 & 5,6 & 5,5 & 5,0 & 4,5 & 4,3 & 3,5 & 4,8 & 6,8 & 7,8 & 4,2 & 4,6 & $-2,6$ \\
\hline Primary budget balance & $\%$ of GDP & 0,0 & 0,1 & 0,5 & 1,9 & 1,9 & 1,7 & 3,1 & 2,9 & $-2,7$ & $-2,7$ & $-3,4$ & 0,7 & 0,4 & 3,4 \\
\hline Growth of GDP & $\%$ & 14,4 & 13,3 & 12,2 & 12,1 & 11,0 & 14,9 & 18,2 & 16,5 & 3,9 & $-10,3$ & $-1,6$ & $-10,3$ & $-1,6$ & \\
\hline Cost of public debt & $\%$ & & 4,4 & 4,7 & 4,0 & 4,0 & 4,6 & 5,3 & 5,4 & 8,9 & 5,6 & 7,2 & 5,6 & 7,2 & \\
\hline 1st sustainability criteria & & 0,5 & 0,5 & 1,0 & 2,4 & 2,3 & 2,2 & 3,7 & 3,3 & $-2,8$ & $-3,7$ & $-4,0$ & 0,0 & 0,0 & \\
\hline 2nd sustainability criteria & & 0,7 & 0,5 & 0,9 & 2,3 & 2,2 & 2,2 & 3,7 & 3,3 & $-2,9$ & $-3,8$ & $-4,1$ & 0,0 & 0,0 & \\
\hline Finland & & & & & & & Data & & & & & & $\begin{array}{r}\text { Simula } \\
\text { under th } \\
\text { condit }\end{array}$ & $\begin{array}{l}\text { ition } \\
\text { e two } \\
\text { ions }\end{array}$ & Difference \\
\hline Variable & Unit & 2000 & 2001 & 2002 & 2003 & 2004 & 2005 & 2006 & 2007 & 2008 & 2009 & 2010 & 2009 & 2010 & $2009 \quad 2010$ \\
\hline Total budget balance & $\%$ of GDP & 6,9 & 5,0 & 4,1 & 2,6 & 2,4 & 2,8 & 4,0 & 5,2 & 4,2 & $-0,8$ & $-2,9$ & 0,9 & $-0,6$ & $\begin{array}{ll}1,7 & 2,3\end{array}$ \\
\hline Public debt & $\%$ of GDP & 43,8 & 42,3 & 41,3 & 44,4 & 44,2 & 41,4 & 39,2 & 35,1 & 33,4 & 39,7 & 45,7 & 31,3 & 32,9 & $-8,4 \quad-12,8$ \\
\hline Primary budget balance & $\%$ of GDP & 9,7 & 7,6 & 6,2 & 4,3 & 4,0 & 4,3 & 5,4 & 6,7 & 5,6 & 0,5 & $-1,5$ & 2,2 & 0,7 & $1,7 \quad 2,2$ \\
\hline Growth of GDP & $\%$ & 7,8 & 5,7 & 2,9 & 1,4 & 4,4 & 3,2 & 6,3 & 7,6 & 3,6 & $-3,0$ & 1,8 & $-3,0$ & 1,8 & \\
\hline Cost of public debt & $\%$ & & 6,3 & 5,1 & 4,2 & 3,8 & 3,5 & 3,6 & 4,1 & 4,1 & 3,8 & 3,6 & 3,8 & 3,6 & \\
\hline 1st sustainability criteria & & 10,3 & 7,4 & 5,3 & 3,2 & 4,3 & 4,1 & 6,5 & 7,9 & 5,4 & $-2,0$ & $-2,1$ & 0,0 & 0,0 & \\
\hline 2nd sustainability criteria & & 13,1 & 7,4 & 5,3 & 3,1 & 4,3 & 4,2 & 6,5 & 7,9 & 5,4 & $-2,2$ & $-2,3$ & 0,1 & 0,1 & \\
\hline France & & & & & & & Data & & & & & & $\begin{array}{r}\text { Simula } \\
\text { under th } \\
\text { condit } \\
\end{array}$ & $\begin{array}{l}\text { tion } \\
\text { e two } \\
\text { ions } \\
\end{array}$ & Difference \\
\hline Variable & Unit & 2000 & 2001 & 2002 & 2003 & 2004 & 2005 & 2006 & 2007 & 2008 & 2009 & 2010 & 2009 & 2010 & $2009 \quad 2010$ \\
\hline Total budget balance & $\%$ of GDP & $-1,5$ & $-1,5$ & $-3,1$ & $-4,1$ & $-3,6$ & $-2,9$ & $-2,3$ & $-2,7$ & $-3,4$ & $-6,6$ & $-7,0$ & 1,3 & $-0,7$ & $7,9 \quad 6,3$ \\
\hline Public debt & $\%$ of GDP & 57,3 & 56,9 & 58,8 & 62,9 & 64,9 & 66,4 & 63,7 & 63,8 & 68,0 & 79,7 & 86,0 & 64,7 & 66,5 & $-15,0 \quad-19,5$ \\
\hline Primary budget balance & $\%$ of GDP & 1,4 & 1,5 & $-0,2$ & $-1,3$ & $-0,9$ & $-0,3$ & 0,3 & 0,0 & $-0,6$ & $-3,8$ & $-4,0$ & 4,1 & 2,1 & $7,9 \quad 6,1$ \\
\hline Growth of GDP & $\%$ & 5,4 & 3,9 & 3,4 & 3,0 & 4,1 & 4,0 & 4,7 & 4,9 & 3,0 & $-1,6$ & 1,0 & $-1,6$ & 1,0 & \\
\hline Cost of public debt & $\%$ & & 5,4 & 5,3 & 4,9 & 4,5 & 4,2 & 4,1 & 4,4 & 4,5 & 4,1 & 3,8 & 4,1 & 3,8 & \\
\hline 1st sustainability criteria & & 1,6 & 0,7 & $-1,1$ & $-2,2$ & $-0,9$ & $-0,2$ & 0,7 & 0,4 & $-1,4$ & $-7,9$ & $-6,1$ & 0,3 & 0,0 & \\
\hline 2nd sustainability criteria & & 4,5 & 0,6 & $-1,3$ & $-2,5$ & $-1,1$ & $-0,4$ & 0,7 & 0,3 & $-1,6$ & $-8,3$ & $-6,4$ & 0,4 & 0,2 & \\
\hline Germany & & & & & & & Data & & & & & & $\begin{array}{r}\text { Simula } \\
\text { under th } \\
\text { condit } \\
\end{array}$ & $\begin{array}{l}\text { tion } \\
\text { e two } \\
\text { ions } \\
\end{array}$ & Difference \\
\hline Variable & Unit & 2000 & 2001 & 2002 & 2003 & 2004 & 2005 & 2006 & 2007 & 2008 & 2009 & 2010 & 2009 & 2010 & $2009 \quad 2010$ \\
\hline Total budget balance & $\%$ of GDP & 1,3 & $-2,8$ & $-3,7$ & $-4,0$ & $-3,8$ & $-3,3$ & $-1,5$ & $-0,2$ & $-0,1$ & $-3,9$ & $-5,9$ & 2,8 & $-0,6$ & $6,7 \quad 5,3$ \\
\hline Public debt & $\%$ of GDP & 59,7 & 58,8 & 60,3 & 63,8 & 65,6 & 67,8 & 67,6 & 65,1 & 65,9 & 73,4 & 78,7 & 61,2 & 64,5 & $-12,2 \quad-14,2$ \\
\hline Primary budget balance & $\%$ of GDP & 4,5 & 0,2 & $-0,7$ & $-1,1$ & $-1,0$ & $-0,5$ & 1,3 & 2,6 & 2,6 & $-1,0$ & $-2,9$ & 5,7 & 2,3 & $6,7 \quad 5,2$ \\
\hline Growth of GDP & $\%$ & 2,5 & 2,5 & 1,4 & 1,0 & 2,2 & 1,5 & 3,5 & 4,4 & 2,9 & $-4,2$ & 1,0 & $-4,2$ & 1,0 & \\
\hline Cost of public debt & $\%$ & & 5,1 & 5,2 & 4,9 & 4,5 & 4,3 & 4,3 & 4,3 & 4,3 & 4,2 & 4,1 & 4,2 & 4,1 & \\
\hline 1st sustainability criteria & & 2,8 & $-1,4$ & $-2,8$ & $-3,4$ & $-2,4$ & $-2,3$ & 0,9 & 2,6 & 1,8 & $-7,0$ & $-5,1$ & 0,2 & 0,0 & \\
\hline 2nd sustainability criteria & & 6,0 & $-1,4$ & $-3,0$ & $-3,6$ & $-2,5$ & $-2,4$ & 0,8 & 2,6 & 1,7 & $-7,2$ & $-5,4$ & 0,5 & 0,3 & \\
\hline Greece & & & & & & & Data & & & & & & $\begin{array}{r}\text { Simula } \\
\text { under th } \\
\text { condit }\end{array}$ & $\begin{array}{l}\text { tion } \\
\text { e two } \\
\text { ions }\end{array}$ & Difference \\
\hline Variable & Unit & 2000 & 2001 & 2002 & 2003 & 2004 & 2005 & 2006 & 2007 & 2008 & 2009 & 2010 & 2009 & 2010 & 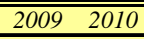 \\
\hline Total budget balance & $\%$ of GDP & $-3,7$ & $-4,5$ & $-4,8$ & $-5,7$ & $-7,5$ & $-5,1$ & $-2,8$ & $-3,6$ & $-5,0$ & $-5,1$ & $-5,7$ & $-1,0$ & $-2,5$ & $\begin{array}{ll}4,1 & 3,2 \\
\end{array}$ \\
\hline Public debt & $\%$ of GDP & 101,8 & 102,9 & 101,5 & 97,8 & 98,6 & 98,8 & 95,9 & 94,8 & 97,6 & 103,4 & 108,0 & 92,6 & 94,1 & $-10,8 \quad-13,9$ \\
\hline Primary budget balance & $\%$ of GDP & 3,6 & 2,0 & 0,7 & $-0,7$ & $-2,6$ & $-0,7$ & 1,3 & 0,5 & $-0,7$ & $-0,5$ & $-0,9$ & 3,6 & 2,1 & $4,1 \quad 3,0$ \\
\hline Growth of GDP & $\%$ & 10,4 & 7,4 & 7,0 & 9,4 & 8,4 & 6,3 & 7,9 & 7,0 & 6,5 & 1,1 & 2,7 & 1,1 & 2,7 & \\
\hline Cost of public debt & $\%$ & & 6,9 & 5,7 & 5,4 & 5,4 & 4,7 & 4,5 & 4,6 & 4,8 & 4,8 & 4,8 & 4,8 & 4,8 & \\
\hline 1st sustainability criteria & & 6,9 & 3,1 & 2,3 & 3,5 & 0,8 & 1,1 & 4,8 & 3,0 & 1,3 & $-4,0$ & $-2,8$ & 0,0 & 0,0 & \\
\hline 2nd sustainability criteria & & 14,2 & 2,6 & 2,0 & 3,2 & 0,3 & 0,8 & 4,6 & 2,8 & 0,9 & $-4,3$ & $-3,1$ & 0,2 & 0,2 & \\
\hline Hungary & & & & & & & Data & & & & & & $\begin{array}{r}\text { Simula } \\
\text { under th } \\
\text { condit }\end{array}$ & $\begin{array}{l}\text { tion } \\
\text { e two } \\
\text { ions } \\
\end{array}$ & Difference \\
\hline Variable & Unit & 2000 & 2001 & 2002 & 2003 & 2004 & 2005 & 2006 & 2007 & 2008 & 2009 & 2010 & 2009 & 2010 & $2009 \quad 2010$ \\
\hline Total budget balance & $\%$ of GDP & $-2,9$ & $-4,0$ & $-9,0$ & $-7,2$ & $-6,4$ & $-7,8$ & $-9,2$ & $-4,9$ & $-3,4$ & $-3,4$ & $-3,9$ & 1,6 & $-2,2$ & $\begin{array}{ll}5,0 & 1,7 \\
\end{array}$ \\
\hline Public debt & $\%$ of GDP & 54,2 & 52,1 & 55,8 & 58,1 & 59,4 & 61,7 & 65,6 & 65,8 & 73,0 & 80,8 & 82,3 & 68,5 & 72,1 & $-12,3 \quad-10,2$ \\
\hline Primary budget balance & $\%$ of GDP & 2,4 & 0,6 & $-4,9$ & $-3,1$ & $-2,0$ & $-3,7$ & $-5,3$ & $-0,9$ & 0,8 & 1,4 & 1,0 & 6,4 & 2,6 & $5,0 \quad 1,6$ \\
\hline Growth of GDP & $\%$ & 15,6 & 12,9 & 12,3 & 10,3 & 9,4 & 6,3 & 8,1 & 6,9 & 4,1 & $-2,0$ & 3,0 & $-2,0$ & & \\
\hline Cost of public debt & $\%$ & & 9,6 & 8,8 & 8,1 & 8,3 & 7,3 & 6,8 & 6,5 & 6,6 & 6,4 & 6,2 & 6,4 & 6,2 & \\
\hline 1st sustainability criteria & & 5,6 & 2,7 & $-2,1$ & $-1,2$ & $-0,8$ & $-3,9$ & $-3,9$ & $-0,4$ & $-0,4$ & $-5,0$ & $-1,4$ & 0,2 & 0,0 & \\
\hline 2nd sustainability criteria & & 10,9 & 2,3 & $-3,0$ & $-1,8$ & $-1,3$ & $-4,3$ & $-4,5$ & $-0,6$ & $-1,1$ & $-5,4$ & $-1,7$ & 0,6 & & \\
\hline
\end{tabular}




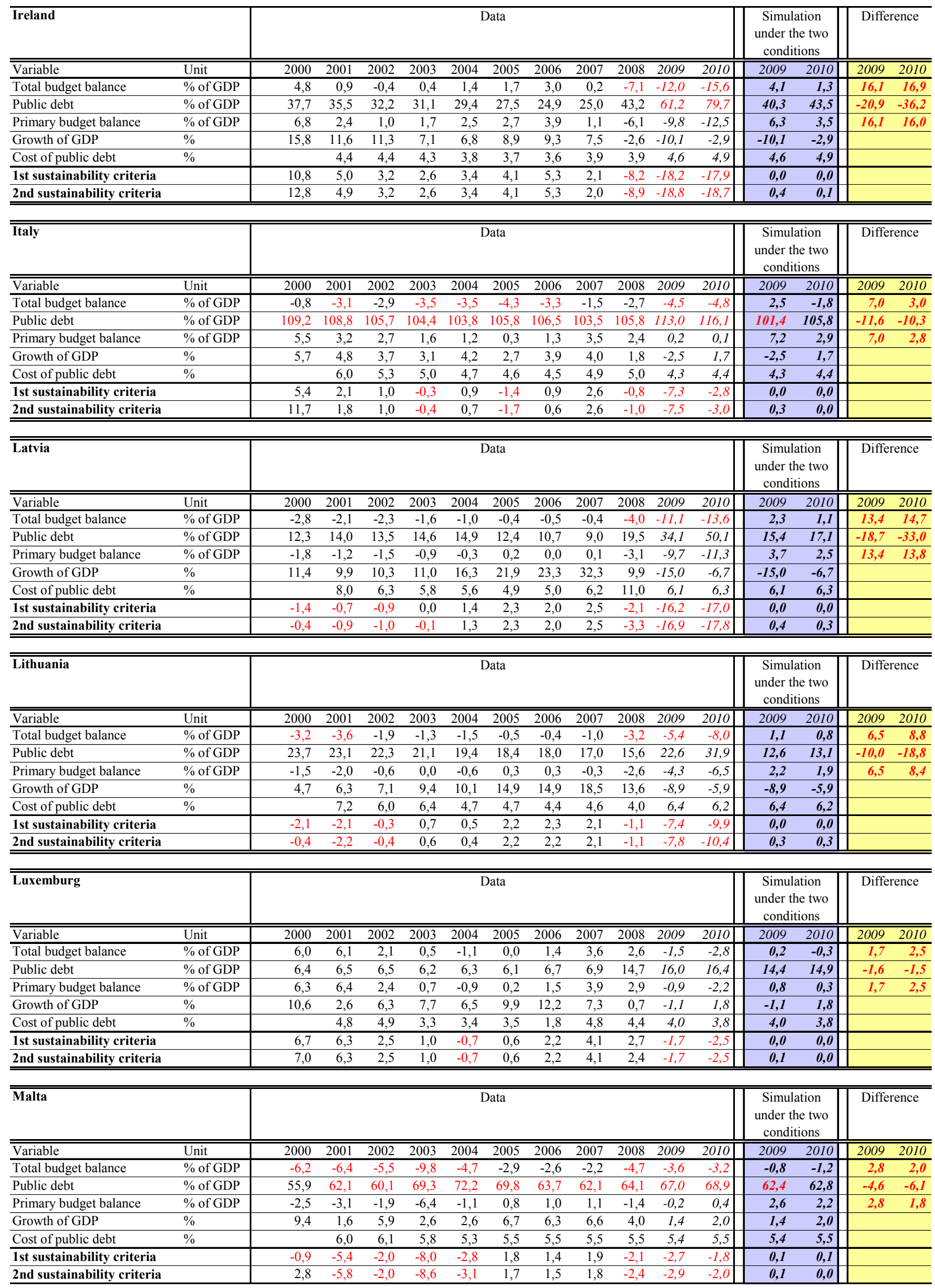




\begin{tabular}{|c|c|c|c|c|c|c|c|c|c|c|c|c|c|c|c|}
\hline \multirow[t]{2}{*}{$\begin{array}{l}\text { Netherlands } \\
\text { Variable } \\
\end{array}$} & \multirow[b]{2}{*}{ Unit } & \multicolumn{11}{|c|}{ Data } & \multicolumn{2}{|c|}{$\begin{array}{c}\text { Simulation } \\
\text { under the two } \\
\text { conditions }\end{array}$} & Difference \\
\hline & & 2000 & 2001 & 2002 & 2003 & 2004 & 2005 & 2006 & 2007 & 2008 & 2009 & 2010 & 2009 & 2010 & $2009 \quad 2010$ \\
\hline Total budget balance & $\%$ of GDP & 2,0 & $-0,2$ & $-2,1$ & $-3,1$ & $-1,7$ & $-0,3$ & 0,6 & 0,3 & 1,0 & $-3,4$ & $-6,1$ & 1,0 & $-0,3$ & $4,4 \quad 5,8$ \\
\hline Public debt & $\%$ of GDP & 53,8 & 50,7 & 50,5 & 52,0 & 52,4 & 51,8 & 47,4 & 45,6 & 58,2 & 57,0 & 63,1 & 54,5 & 55,8 & $-2,5$ \\
\hline Primary budget balance & $\%$ of GDP & 5,6 & 2,9 & 0,7 & $-0,6$ & 0,7 & 2,1 & 2,8 & 2,6 & 3,2 & $-0,8$ & $-3,4$ & 3,6 & 2,3 & 4,4 \\
\hline Growth of GDP & $\%$ & 8,2 & 7,1 & 3,9 & 2,5 & 3,0 & 4,5 & 5,2 & 5,0 & 4,9 & $-1,9$ & 0,7 & $-1,9$ & 0,7 & \\
\hline Cost of public debt & $\%$ & & 6,2 & 5,7 & 5,1 & 4,8 & 4,8 & 4,5 & 5,1 & 5,1 & 4,4 & 4,8 & 4,4 & 4,8 & \\
\hline 1st sustainability criteria & & 6,4 & 3,4 & $-0,1$ & $-1,8$ & $-0,1$ & 2,0 & 3,1 & 2,6 & 3,9 & $-4,5$ & $-5,7$ & 0,0 & 0,1 & \\
\hline 2nd sustainability criteria & & 10,0 & 3,4 & $-0,2$ & $-1,9$ & $-0,2$ & 2,0 & 3,1 & 2,6 & 3,1 & $-4,4$ & $-6,0$ & 0,2 & 0,0 & \\
\hline Poland & & & & & & & Data & & & & & & $\begin{array}{r}\text { Simule } \\
\text { under th } \\
\text { condit }\end{array}$ & $\begin{array}{l}\text { tion } \\
\text { e two } \\
\text { ions }\end{array}$ & Difference \\
\hline Variable & Unit & 2000 & 2001 & 2002 & 2003 & 2004 & 2005 & 2006 & 2007 & 2008 & 2009 & 2010 & 2009 & 2010 & $2009 \quad 2010$ \\
\hline Total budget balance & $\%$ of GDP & $-3,0$ & $-5,1$ & $-5,0$ & $-6,3$ & $-5,7$ & $-4,3$ & $-3,9$ & $-1,9$ & $-3,9$ & $-6,6$ & \begin{tabular}{|c|}
$-7,3$ \\
\end{tabular} & $-0,2$ & $-1,1$ & $6,4 \quad 6,2$ \\
\hline Public debt & $\%$ of GDP & 36,8 & 37,6 & 42,2 & 47,1 & 45,7 & 47,1 & 47,7 & 44,9 & 47,1 & 53,6 & 59,7 & 43,7 & 44,6 & $-9,9-15,1$ \\
\hline Primary budget balance & $\%$ of GDP & 0,0 & $-2,0$ & $-2,1$ & $-3,3$ & $-2,9$ & $-1,5$ & $-1,2$ & 0,4 & $-1,7$ & $-3,7$ & $-4,3$ & 2,7 & 1,8 & $6,4 \quad 6,1$ \\
\hline Growth of GDP & $\%$ & 11,8 & 4,7 & 3,7 & 4,3 & 9,7 & 6,4 & 7,8 & 10,9 & 8,2 & 0,5 & 2,4 & 0,5 & 2,4 & \\
\hline Cost of public debt & $\%$ & & 8,8 & 8,0 & 7,4 & 6,5 & 6,5 & 6,2 & 5,3 & 5,3 & 6,2 & 5,7 & 6,2 & 5,7 & \\
\hline 1st sustainability criteria & & 1,3 & $-3,3$ & $-3,4$ & $-4,3$ & $-1,3$ & $-1,3$ & $-0,2$ & 3,0 & 0,0 & $-6,3$ & $-5,9$ & 0,0 & 0,0 & \\
\hline 2nd sustainability criteria & & 4,3 & $-3,5$ & $-3,9$ & $-4,8$ & $-1,4$ & $-1,6$ & $-0,4$ & 2,9 & $-0,3$ & $-6,7$ & $-6,3$ & 0,2 & 0,3 & \\
\hline Portugal & & & & & & & Data & & & & & & $\begin{array}{r}\text { Simulc } \\
\text { under th } \\
\text { condit } \\
\end{array}$ & $\begin{array}{l}\text { ition } \\
\text { e two } \\
\text { ions }\end{array}$ & Difference \\
\hline Variable & Unit & 2000 & 2001 & 2002 & 2003 & 2004 & 2005 & 2006 & 2007 & 2008 & 2009 & 2010 & 2009 & 2010 & $2009 \quad 2010$ \\
\hline Total budget balance & $\%$ of GDP & $-2,9$ & $-4,3$ & $-2,8$ & $-2,9$ & $-3,4$ & $-6,1$ & $-3,9$ & $-2,6$ & $-2,6$ & $-6,5$ & $-6,7$ & 1,0 & $-0,5$ & $7,5 \quad 6,2$ \\
\hline Public debt & $\%$ of GDP & 50,4 & 52,9 & 55,5 & 56,9 & 58,3 & 63,6 & 64,7 & 63,5 & 66,4 & 75,4 & 81,5 & 64,2 & 65,7 & $-11,2-15,8$ \\
\hline Primary budget balance & $\%$ of GDP & 0,1 & $-1,3$ & 0,0 & $-0,2$ & $-0,7$ & $-3,5$ & $-1,2$ & 0,2 & 0,3 & $-3,6$ & $-3,4$ & 3,9 & 2,4 & $7,5 \quad 5,8$ \\
\hline Growth of GDP & $\%$ & 7,1 & 5,8 & 4,7 & 2,3 & 4,0 & 3,5 & 4,2 & 5,0 & 1,8 & $-1,5$ & 0,8 & $-1,5$ & 0,8 & \\
\hline Cost of public debt & $\%$ & & 6,3 & 5,5 & 5,0 & 4,9 & 4,6 & 4,4 & 4,5 & 4,6 & 4,3 & 4,4 & 4,3 & 4,4 & \\
\hline 1st sustainability criteria & & 0,7 & $-1,2$ & $-0,2$ & $-1,6$ & $-1,1$ & $-3,9$ & $-1,2$ & 0,6 & $-1,4$ & \begin{tabular}{ll|}
$-7,6$ \\
\end{tabular} & $-6,0$ & 0,0 & 0,0 & \\
\hline 2nd sustainability criteria & & 3,7 & $-1,6$ & $-0,5$ & $-1,7$ & $\begin{array}{ll}-1,2 \\
\end{array}$ & $-4,2$ & $-1,3$ & 0,5 & $-1,6$ & $-8,0$ & \begin{tabular}{ll|}
$-6,3$ \\
\end{tabular} & 0,2 & 0,0 & \\
\hline Romania & & & & & & & Jata & & & & & & $\begin{array}{r}\text { Simul } \\
\text { under th } \\
\text { condit } \\
\end{array}$ & $\begin{array}{l}\text { ition } \\
\text { e two } \\
\text { ions }\end{array}$ & Difference \\
\hline $\begin{array}{l}\text { Variable } \\
\end{array}$ & Unit & 2000 & 2001 & 2002 & 2003 & 2004 & 2005 & 2006 & 2007 & 2008 & 2009 & 2010 & 2009 & 2010 & $2009 \quad 2010$ \\
\hline Total budget balance & $\%$ of GDP & $-4,7$ & $-3,5$ & $-2,0$ & $-1,5$ & $-1,2$ & $-1,2$ & $-2,2$ & $-2,5$ & $-5,4$ & $-5,1$ & $-5,6$ & $-0,6$ & $-0,8$ & $4,5 \quad 4,8$ \\
\hline Public debt & $\%$ of GDP & 24,6 & 25,7 & 24,9 & 21,5 & 18,7 & 15,8 & 12,4 & 12,7 & 13,6 & 18,2 & 22,7 & 11,7 & 11,9 & $-6,5-10,8$ \\
\hline Primary budget balance & $\%$ of GDP & $-0,7$ & $-0,1$ & 0,5 & 0,1 & 0,2 & $-0,1$ & $-1,3$ & $-1,8$ & $-4,7$ & $-3,6$ & $-4,0$ & 0,9 & 0,7 & $4,5 \quad 4,7$ \\
\hline Growth of GDP & $\%$ & 48,4 & 45,6 & 28,9 & 29,9 & 25,3 & 16,8 & 19,3 & 19,8 & 22,1 & 5,3 & 6,6 & 5,3 & 6,6 & \\
\hline Cost of public debt & $\%$ & & 20,1 & 12,5 & 8,3 & 8,2 & 6,9 & 6,8 & 6,8 & 6,7 & 11,6 & 9,4 & 11,6 & 9,4 & \\
\hline 1st sustainability criteria & & 7,2 & 8,2 & 5,2 & 4,9 & 3,5 & 1,5 & 0,2 & 0,0 & $-2,4$ & $-4,1$ & $-4,1$ & 0,0 & 0,0 & \\
\hline 2nd sustainability criteria & & 11,2 & 6,4 & 4,6 & 4,7 & 3,4 & 1,5 & 0,3 & $-0,1$ & $-2,6$ & $-4,7$ & $-4,6$ & 0,2 & 0,4 & \\
\hline $\begin{array}{l}\text { Slovenia } \\
\end{array}$ & & & & & & & Data & & & & & & $\begin{array}{r}\text { Simul } \\
\text { under th } \\
\text { condit } \\
\end{array}$ & $\begin{array}{l}\text { ation } \\
\text { le two } \\
\text { ions }\end{array}$ & Difference \\
\hline Variable & Unit & 2000 & 2001 & 2002 & 2003 & 2004 & 2005 & 2006 & 2007 & 2008 & 2009 & 2010 & 2009 & 2010 & $2009 \quad 2010$ \\
\hline Total budget balance & $\%$ of GDP & $-3,8$ & $-4,1$ & $-2,5$ & $-2,7$ & $-2,2$ & $-1,4$ & $-1,3$ & 0,5 & \begin{tabular}{c|c|}
$-0,9$ \\
\end{tabular} & $-5,5$ & $-6,5$ & 0,4 & $-0,6$ & $\begin{array}{rr}5,9 \quad 5,9 \\
\end{array}$ \\
\hline Public debt & $\%$ of Gl & 26,8 & 27,4 & 28,1 & 27,5 & 27,2 & 27,0 & 26,7 & 23,4 & 22,8 & 29,3 & 34,9 & 20,6 & 21,5 & $-8,7 \quad-13,4$ \\
\hline Primary budget balance & $\%$ of GDP & $-1,4$ & $-1,7$ & $-0,3$ & $-0,7$ & $-0,5$ & 0,1 & 0,1 & 1,8 & 0,2 & $-3,9$ & $-4,7$ & 2,0 & 1,0 & $5,9 \quad 5,7$ \\
\hline Growth of GDP & $\%$ & 10,0 & 11,8 & 12,0 & 8,6 & 7,8 & 6,0 & 8,0 & 11,2 & 8,8 & $-1,6$ & 2,8 & $-1,6$ & 2,8 & \\
\hline Cost of public debt & $\%$ & & 10,0 & 9,0 & 7,7 & 6,7 & 5,8 & 5,6 & 5,4 & 5,1 & 6,9 & 6,3 & 6,9 & 6,3 & \\
\hline 1st sustainability crit & & $-1,1$ & $-0,9$ & 0,9 & $-0,3$ & $-0,1$ & 0,2 & 0,8 & 3,1 & 1,1 & $-6,0$ & $-5,5$ & 0,1 & 0,0 & \\
\hline 2nd sustainability criteria & & 1,3 & $-1,2$ & 0,5 & $-0,5$ & $-0,2$ & 0,1 & 0,7 & 3,2 & 1,0 & $-6,4$ & $-5,9$ & 0,3 & 0,2 & \\
\hline Slovakia & & & & & & & Jata & & & & & & $\begin{array}{r}\text { Simule } \\
\text { under th } \\
\text { condit }\end{array}$ & $\begin{array}{l}\text { tion } \\
\text { e two } \\
\text { ions }\end{array}$ & Difference \\
\hline Variable & & 2000 & 2001 & 2002 & 2003 & 2004 & 2005 & 2006 & 2007 & 2008 & 2009 & 2010 & 2009 & 2010 & $2009 \quad 2010$ \\
\hline Total budget balance & $\%$ of GDP & $-12,3$ & $-6,5$ & $-8,2$ & $-2,8$ & $-2,4$ & $-2,8$ & $-3,5$ & $-1,9$ & $-2,2$ & $-4,7$ & $-5,4$ & $-0,3$ & $-1,2$ & $4,4 \quad 4,2$ \\
\hline Public debt & $\%$ of GDP & 50,3 & 48,9 & 43,4 & 42,4 & 41,4 & 34,2 & 30,4 & 29,4 & 27,6 & 32,2 & 36,3 & 25,5 & 26,5 & $-6,7$ \\
\hline Primary budget balance & $\%$ of GDP & $-8,2$ & $-2,5$ & $-4,7$ & $-0,3$ & $-0,2$ & $-1,1$ & $-2,0$ & $-0,5$ & $-0,9$ & $-3,3$ & $-4,0$ & 1,1 & 0,2 & 4,4 \\
\hline Growth of GDP & $\%$ & 10,9 & 8,6 & 8,8 & 10,3 & 11,3 & 9,1 & 11,7 & 11,7 & 9,5 & 1,0 & 4,4 & 1,0 & 4,4 & \\
\hline Cost of public debt & $\%$ & & 8,6 & 7,8 & 6,4 & 5,8 & 4,5 & 4,9 & 5,1 & 4,8 & 5,1 & 4,5 & 5,1 & 4,5 & \\
\hline 1st sustainability criteria & & $-6,8$ & $-2,3$ & $-4,4$ & 1,6 & 2,3 & 0,3 & 0,1 & 1,5 & 0,4 & $-4,4$ & $-3,8$ & 0,0 & 0,0 & \\
\hline 2nd sustainability criteria & & $-2,7$ & $-2,5$ & $-4,3$ & 1,4 & 2,1 & 0,5 & 0,1 & 1,4 & 0,4 & $-4,6$ & $-4,1$ & 0,0 & 0,2 & \\
\hline
\end{tabular}




\begin{tabular}{|c|c|c|c|c|c|c|c|c|c|c|c|c|c|c|c|c|}
\hline \multirow{2}{*}{$\begin{array}{l}\text { Spain } \\
\text { Variable }\end{array}$} & \multirow[b]{2}{*}{ Unit } & \multicolumn{11}{|c|}{ Data } & \multicolumn{2}{|c|}{$\begin{array}{c}\text { Simulation } \\
\text { under the two } \\
\text { conditions }\end{array}$} & \multicolumn{2}{|c|}{ Difference } \\
\hline & & 2000 & 2001 & 2002 & 2003 & 2004 & 2005 & 2006 & 2007 & 2008 & 2009 & 2010 & 2009 & 2010 & 2009 & 2010 \\
\hline Total budget balance & $\%$ of GDP & $-1,0$ & $-0,6$ & $-0,5$ & $-0,2$ & $-0,3$ & 1,0 & 2,0 & 2,2 & $-3,8$ & $-8,6$ & $-9,8$ & 0,9 & $-0,3$ & 9,5 & 9,5 \\
\hline Public debt & $\%$ of GDP & 59,2 & 55,5 & 52,5 & 48,7 & 46,2 & 43,0 & 39,6 & 36,2 & 39,5 & 50,8 & 62,3 & 37,0 & 38,1 & $-13,8$ & $-24,2$ \\
\hline Primary budget balance & $\%$ of GDP & 2,2 & 2,4 & 2,2 & 2,1 & 1,7 & 2,8 & 3,7 & 3,8 & $-2,3$ & $-6,9$ & $-7,8$ & 2,6 & 1,4 & 9,5 & 9,2 \\
\hline Growth of GDP & $\%$ & 8,7 & 8,0 & 7,1 & 7,4 & 7,4 & 8,1 & 8,1 & 7,0 & 4,2 & $-2,1$ & 0,9 & $-2,1$ & 0,9 & & \\
\hline Cost of public debt & $\%$ & & 5,5 & 5,2 & 4,7 & 4,4 & 4,2 & 4,3 & 4,3 & 4,3 & 4,2 & 4,0 & 4,2 & 4,0 & & \\
\hline 1st sustainability criteria & & 4,2 & 3,8 & 3,2 & 3,4 & 3,1 & 4,5 & 5,2 & 4,7 & $-2,1$ & $-9,7$ & $-9,2$ & 0,1 & 0,0 & & \\
\hline 2nd sustainability criteria & & 7,4 & 3,8 & 3,2 & 3,4 & 3,1 & 4,5 & 5,2 & 4,8 & $-2,3$ & $-10,1$ & $-9,7$ & 0,3 & 0,2 & & \\
\hline Sweden & & & & & & & ata & & & & & & $\begin{array}{r}\text { Simul } \\
\text { under th } \\
\text { condit }\end{array}$ & $\begin{array}{l}\text { tion } \\
\text { e two } \\
\text { ons } \\
\end{array}$ & Diffe & rence \\
\hline Variable & Unit & 2000 & 2001 & 2002 & 2003 & 2004 & 2005 & 2006 & 2007 & 2008 & 2009 & 2010 & 2009 & 2010 & 2009 & 2010 \\
\hline Total budget balance & $\%$ of GDP & 3,7 & 1,6 & $-1,2$ & $-0,9$ & 0,8 & 2,3 & 2,5 & 3,8 & 2,5 & $-2,6$ & $-3,9$ & 1,1 & $-0,6$ & 3,7 & 3,3 \\
\hline Public debt & $\%$ of GDP & 53,6 & 54,4 & 52,6 & 52,3 & 51,2 & 51,0 & 45,9 & 40,5 & 38,0 & 44,0 & 47,2 & 35,8 & 37,3 & $-8,2$ & $-9,9$ \\
\hline Primary budget balance & $\%$ of GDP & 7,2 & 4,4 & 1,7 & 1,1 & 2,4 & 3,9 & 4,2 & 5,6 & 4,2 & $-1,2$ & $-2,5$ & 2,5 & 0,8 & 3,7 & 3,3 \\
\hline Growth of GDP & $\%$ & 5,9 & 3,4 & 4,1 & 3,9 & 4,4 & 4,2 & 6,1 & 5,6 & 3,1 & $-2,5$ & 1,7 & $-2,5$ & 1,7 & & \\
\hline Cost of public debt & $\%$ & & 5,4 & 5,5 & 4,0 & 3,2 & 3,3 & 3,5 & 4,1 & 4,3 & 3,6 & 3,2 & 3,6 & 3,2 & & \\
\hline 1st sustainability criteria & & 6,9 & 3,4 & 1,0 & 1,1 & 3,1 & 4,4 & 5,3 & 6,1 & 3,7 & $-3,7$ & $-3,1$ & 0,2 & 0,0 & & \\
\hline 2nd sustainability criteria & & 10,4 & 3,3 & 0,9 & 1,1 & 3,0 & 4,4 & 5,4 & 6,2 & 3,7 & $-3,9$ & $-3,2$ & 0,3 & 0,2 & & \\
\hline United Kingdom & & & & & & & ata & & & & & & $\begin{array}{r}\text { Simul } \\
\text { under tl } \\
\text { condit }\end{array}$ & $\begin{array}{l}\text { tion } \\
\text { e two } \\
\text { ons }\end{array}$ & Diffe & rence \\
\hline Variable & Unit & 2000 & 2001 & 2002 & 2003 & 2004 & 2005 & 2006 & 2007 & 2008 & 2009 & 2010 & 2009 & 2010 & 2009 & 2010 \\
\hline Total budget balance & $\%$ of GDP & 3,6 & 0,5 & $-2,0$ & $-3,3$ & $-3,4$ & $-3,4$ & $-2,7$ & $-2,7$ & $-5,5$ & $-11,5$ & $-13,8$ & 1,7 & $-0,6$ & 13,2 & 13,2 \\
\hline Public debt & $\%$ of GDP & 41,0 & 37,7 & 37,5 & 38,7 & 40,6 & 42,3 & 43,4 & 44,2 & 52,0 & 68,4 & 81,7 & 48,8 & 50,9 & $-19,6$ & $-30,8$ \\
\hline Primary budget balance & $\%$ of GDP & 6,3 & 2,9 & 0,0 & $-1,4$ & $-1,5$ & $-1,3$ & $-0,7$ & $-0,5$ & $-3,1$ & $-9,4$ & $-10,8$ & 3,8 & 1,5 & 13,2 & 12,3 \\
\hline Growth of GDP & $\%$ & 5,1 & 4,6 & 5,3 & 6,0 & 5,3 & 4,3 & 5,5 & 6,0 & 3,0 & $-3,0$ & 1,6 & $-3,0$ & 1,6 & & \\
\hline Cost of public debt & $\%$ & & 6,1 & 5,6 & 5,4 & 5,2 & 5,4 & 5,0 & 5,4 & 5,6 & 3,9 & 4,5 & 3,9 & 4,5 & & \\
\hline 1st sustainability criteria & & 5,7 & 2,2 & 0,0 & $-1,0$ & $-1,2$ & $-1,6$ & $-0,3$ & 0,0 & $-3,9$ & $-13,6$ & $-12,5$ & 0,2 & 0,2 & & \\
\hline 2nd sustainability criteria & & 8,4 & 2,3 & $-0,1$ & $-1,2$ & $-1,4$ & $-1,8$ & $-0,5$ & $-0,2$ & $-4,4$ & $-14,1$ & $-13,1$ & 0,4 & 0,0 & & \\
\hline
\end{tabular}

Notes:

1. Estimates are in Bold.

2. Forecasts are in Italics.

Source: Own calculations based on data from European Commission online database (2009).

\section{FISKALNA ODRŽIVOST ZEMALJA ČLANICA EU U KONTEKSTU TRENUTNE FINANCIJSKE KRIZE}

\section{SAŽETAK}

Rad se bavi pitanjem fiskalne održivosti u trenutnoj financijskoj i ekonomskoj krizi. Iz literature se može zaključiti da je, u pogledu fiskalne stabilnosti, postavljanje fiksnog ograničenja u omjer odnosa javnog duga prema BDP-u i budžetne bilance prema BDP-u previše pojednostavljeno rješenje i kako bi održiva fiskalna politika mogla biti definirana gornjim granicama odnosa javnog duga prema BDP-u i budžetne bilance prema BDP-u, uzimajući u obzir neke parametre specifične za pojedinu zemlju. Naša empirijska analiza pokazuje da je većina zemalja članica EU ušla u 2008. godinu sa zdravim javnim financijama. Ipak, većina zemalja članica EU se sada nalazi u financijskim problemima. Čak štoviše, gotovo sve zemlje članice EU moraju u 2009. i 2010. smanjiti budžetni deficit kako bi dostigle održivu budžetnu poziciju. Veliki skokovi u budžetnom deficitu u 2009. i 2010., u usporedbi s 2007. (prije krize) uglavnom su uzrokovani manjim fiskalnim primanjima koja su posljedica smanjenog ekonomskog rasta i mjera za suzbijanje financijske i ekonomske krize. Mi tvrdimo da te promjene u fiskalnim deficitima nisu održive. Naša analiza pokazuje da bi u 2009. oko 2/3 gospodarstava o kojima govorimo trebalo imati proračunski višak uzimajući u obzir ostale relevantne makroekonomske varijable kao što su gospodarski rast, itd. U 2010. bi ipak bilo moguće provoditi opušteniju fiskalnu politiku ali bi još uvijek bio održiv znatno niži fiskalni deficit od prognoziranog.

Ključne riječi: Javne financije, održivost, budžetna bilanca, budžetni deficit, javni dug 